\title{
Economic Determinants of Industrial Water Demand: A Review of the Applied Research Literature
}

\author{
Pilar Gracia-de-Rentería ${ }^{1,2, *(D)}$ and Ramón Barberán ${ }^{3,4}$ (D) \\ 1 Agrifood Research and Technology Centre of Aragon (CITA), Department of Agrifood and Natural Resources \\ Economics, Montañana Avenue, 930, 50059 Zaragoza, Spain \\ 2 Agrifood Institute of Aragon-IA2, CITA-University of Zaragoza, Miguel Servet Street, 177, \\ 50013 Zaragoza, Spain \\ 3 Department of Public Economics, Faculty of Economics and Business, University of Zaragoza, \\ Gran Vía Street, 2, 50005 Zaragoza, Spain; barberan@unizar.es \\ 4 Environmental Science Institute (IUCA), University of Zaragoza, Pedro Cerbuna Street, 2, \\ 50009 Zaragoza, Spain \\ * Correspondence: mpgracia@cita-aragon.es; Tel.: +34-976-716356
}

Citation: Gracia-de-Rentería, P.; Barberán, R. Economic Determinants of Industrial Water Demand: A Review of the Applied Research Literature. Water 2021, 13, 1684. https://doi.org/10.3390/w13121684

Academic Editor: Christos S. Akratos

Received: 26 April 2021

Accepted: 14 June 2021

Published: 17 June 2021

Publisher's Note: MDPI stays neutral with regard to jurisdictional claims in published maps and institutional affiliations.

Copyright: (c) 2021 by the authors. Licensee MDPI, Basel, Switzerland. This article is an open access article distributed under the terms and conditions of the Creative Commons Attribution (CC BY) license (https:// creativecommons.org/licenses/by/ $4.0 /)$.

\begin{abstract}
This paper surveys the empirical economic literature focused on the determinants of industrial water demand. Both the methodological issues and the outcomes of the previous studies are presented and discussed. Attention is given to key methodological issues, such as the available information, the type of data used, the specification of the variables, the choice of the estimated function, its functional form, and the estimation techniques used, highlighting the issues that require greater attention in future studies. Regarding the results, we focus on the estimated elasticities in order to know how the price of water, the level of activity, and the prices of the other inputs influence the demand for water.
\end{abstract}

Keywords: industrial water; demand estimation; determinants; elasticities; review

\section{Introduction}

The growth of population, urbanization, and productive activity, together with the effects of climate change, are exacerbating the water scarcity and water quality problems that face many areas of the planet, endangering people's health, conservation of natural ecosystems, and sustainability of economic development [1]. To moderate these pressures on the water resource and to advance in the compatibility between its different uses and in ensuring its long-term sustainability, public intervention is necessary, especially through the adoption of demand-management policies, such as pricing policy [2-4].

Economists have paid considerable attention to this question through the estimation of the determinants of water demand, that is, the analysis of the effect that water prices and other economic variables have on the users' behaviour regarding the use of water, with the aim of guiding water demand policies, especially pricing policy. In this research field, the studies focusing on urban environments are abundant due to its implications for human health and wellbeing and for economic development. But the attention has mainly focused on household demand and much less on industrial demand despite its importance in urban environments where industrial uses compete with other uses that require drinking water and where pollution from industrial runoff can be a threat to water quality [5]. In the same line, the number of reviews about the determinants of industrial water demand is much reduced [6-8] in comparison with the abundant number of reviews and also meta-analysis focused on domestic demand, e.g. [9-15].

Despite the attention paid by the previous literature, the evidence on the efficiency of water prices as a tool to encourage reduced water use in urban environments is limited and mostly outdated [16]. Evidence is even more limited for other determinants of water demand, such as the interrelation between water from different sources or, in the industrial 
context, the relationship between water and other inputs. Therefore, more studies focusing on the determinants of water demand are needed, especially covering the industrial sector. To make progress in this direction, a literature review is needed as a first step to know what has been done to date and how, as well as what results have been obtained, to take advantage of the methodological experience available to design new research and to have elements of comparison for the new results obtained.

This paper aims at offering an updated and detailed review of the literature about the determinants of industrial water demand. The specific objectives pursued are to analyse the most relevant methodological issues in this research field and the main results obtained by this literature. The former is a useful tool for researchers when estimating industrial water demand and the latter provides valuable information for both researchers and policy makers in charge of water management policies. Therefore, this is a start-of-the-art about a relevant economic field of study that is meant to serve as a guide for future studies, since meta-analysis is outside the scope of this paper.

To conduct this review, the studies included in the previous reviews about the determinants of industrial water demand [6-8] were complemented with a detailed research protocol. The online databases consulted were Web of Science, Scopus, Science Direct, Springer, and Google Scholar. Three types of keywords were selected and combined in order to identify the field of study, the sector, and the source of water supply. The articles identified were carefully reviewed, and those with an economic focus and that estimated relevant elasticities (at least, the price elasticity) were included in this review. Additionally, references and citations of the selected articles were also considered and, if appropriate, included. This research has not been limited neither temporally (thus, covering until the end of 2020) nor geographically (being a worldwide analysis). This resulted in a total of 46 papers selected. After this introduction, Section 2 offers a brief overview of the literature, making a first presentation of topics and authors. Section 3 addresses some of the main methodological challenges when estimating water demand, paying special attention to those issues that have been a subject of discussion in the literature, most of them conditioned by the availability of information. Section 4 summarises and discusses the main results obtained by the literature, both for the publicly supplied water demand or the total intake water demand and for other water inputs, such as self-supply and recirculation. Finally, Section 5 presents the main conclusions obtained by the literature and suggests some issues that needs to receive greater attention in future studies.

\section{A General Overview}

The first papers in this field focused only on analysing the effect of the price of water and the level of activity on the quantity of water demanded, but the raised questions have been refined and diversified over the years. Some of these issues are, for example, the relationship between water and the other inputs involved in the production process, the different use of water between the diverse industrial activities, the consideration of self-supplied and recirculated water as additional water inputs that enter the production process together with publicly supplied water, the relationship between the volume of wastewater, and the amount of intake water or the economic value of industrial water.

One of the seminal works in this field is that of Turnovsky (1969), who was the first paper in assessing the impact of the tariff on the amount of water demanded in the industrial sector [17]. However, its approach was very conditioned by the previous experience accumulated in the domestic sphere, so the water demand function was derived from a utility function in which water was treated as a final consumption good, as in Equation (1).

$$
D_{W}=f\left(Y, P_{W}\right)
$$

where $D_{w}$ is the water demand, $Y$ is the output level, and $P_{w}$ is the price of water.

Grebenstein and Field (1979) redirected this approach in the context of production functions [18] based on previous experience in other natural resources, such as energy or minerals, e.g., [19-21]. Thus, they extended the production approach (see Equation (2)) 
followed by these authors to the case of water for industrial uses, taking the leap towards the cost function in which water appears as an additional input of the production process, as in Equation (3). This approach allows obtaining the conditional water demand as a function of the output level and the input prices, as in equation 4.

$$
\begin{gathered}
Y=f\left(Q_{W}, Q_{K}, Q_{L}, Q_{S}\right) \\
C=f\left(Y, P_{W}, P_{K}, P_{L}, P_{S}\right) \\
D_{W}=f\left(Y, P_{W}, P_{K}, P_{L}, P_{S}\right)
\end{gathered}
$$

where $Y$ is the output level, $C$ is the firm's cost, $D_{w}$ is the water demand, $Q$ is the quantity of input $i$, and $P$ is the price of input $i$, being $i=W, K, L, S$ (water, capital, labour, and supplies, respectively).

At a later stage, Babin et al. (1982) introduced the problem of sectoral heterogeneity, calling into question the existence of a single common cost function for the entire industrial sector [22]. This step is essential, since by explicitly recognizing the specific characteristics of each industrial activity, there is the possibility of different responses in each of them due to similar changes in the input prices. This practice has been generalized, with most papers focusing on one (or a few) manufacturing activities of special interest because of their water utilization [23-26] and also covering the service sector [25,27-31]. However, it is not common to analyse water demand for a vast number of sectors and subsectors, as evidenced by the fact that only seven of the references analysed in this review have considered more than 10 subsectors [32-38].

A common denominator in previous studies based on the cost function is the interest in the relationship (of complementarity or substitutability) between water and other inputs of the production process [18,22,26,30,35-42]. Another dimension of this issue leads to the consideration of different water inputs. Unlike domestic users that usually only collect drinking water from public supply networks (as examples of estimating water demand in households with multiple water sources, see [43-46]), industrial users may employ water for several purposes, some of which do not require a high quality of water. This allows companies to use alternative sources to publicly supplied water, such as self-supply and recirculated water. Publicly supplied water refers to the water that firms receive through an urban public-supply network (usually drinking water), while self-supplied water refers to the water collected by companies using their own facilities and equipment and may have different origins: surface water, groundwater, seawater, and other water resources. Water recirculation refers to water that is used more than once by a company in the production process and to the treatment required for ensuring an acceptable quality.

Empirical studies that analysed the alternative sources of water supply aimed at determining the factors that influence both the decision to self-supply or recirculate water and the decision about the volume of self-supplied and recirculated water demanded, paying a special attention to the impact of the price of water inputs and to the relationship (of complementarity or substitutability) between the different water sources. Despite the importance of these water inputs in many production processes (the first authors that pointed out this issue were De Rooy (1974) and Ziegler and Bell (1984) [23,47]), the attention paid by the literature to these topics is rather scarce. Few papers analysed water recirculation [24,39,48-52] and even fewer analysed self-supplied water [53-56]. Nevertheless, there are a large number of papers that focus on the total intake water (as the sum of publicly and self-supplied water).

At the end of the production process, we find the issue of wastewater volumes that are usually discharged into the natural environment. Therefore, industrial water becomes a potential source of contamination that must be controlled, taking actions to control the total volume of water used in the production process and the total volume of water discharged. Renzetti $(1988,1992)$ and Dupont and Renzetti (1998) focused on the problem of the water treatment required after its use and, specifically, on the expense necessary to comply with the wastewater regulation $[24,48,49]$. The aim of these works was to 
evaluate the effect of the wastewater pricing policy on the volume of water discharged, collected, and recirculated. Afterwards, Reynaud (2003) suggested considering wastewater as a second output of the production process rather than as an input [54]. Féres and Reynaud (2005) also analysed how environmental regulation regarding wastewater can affect the amount of water demanded, since environmental policies can have effects on costs, modifying internal input allocation [40].

Another strand of the literature focused on the economic value of water, deriving the shadow price of water from the production function $[32,34,37,38,41,57]$, or the cost function [30]. In addition, some of these papers also calculate the direct and/or cross-price elasticities of water.

\section{Methodological Issues}

\subsection{Data and Problems Linked to Lack of Information}

One of the main pitfalls when estimating the demand for water is the lack of accurate information, since access to microdata coming from official surveys or administrative records is restricted, and researchers do not usually have the capacity to generate their own databases with the required dimension. This problem is especially marked when analysing the demand for water for industrial uses and conditions several formal aspects of the analysis. Table 1 shows the main characteristics of the data used.

One can verify that studies have usually focused on analysing a single country and that there are no studies aimed at comparing international differences on the factors that determine the demand for industrial water. Regarding this geographical scope, most of the studies focused on the case of the United States or Canada, while the studies concentrated on the European case or on developing countries are less abundant (see Figure 1).

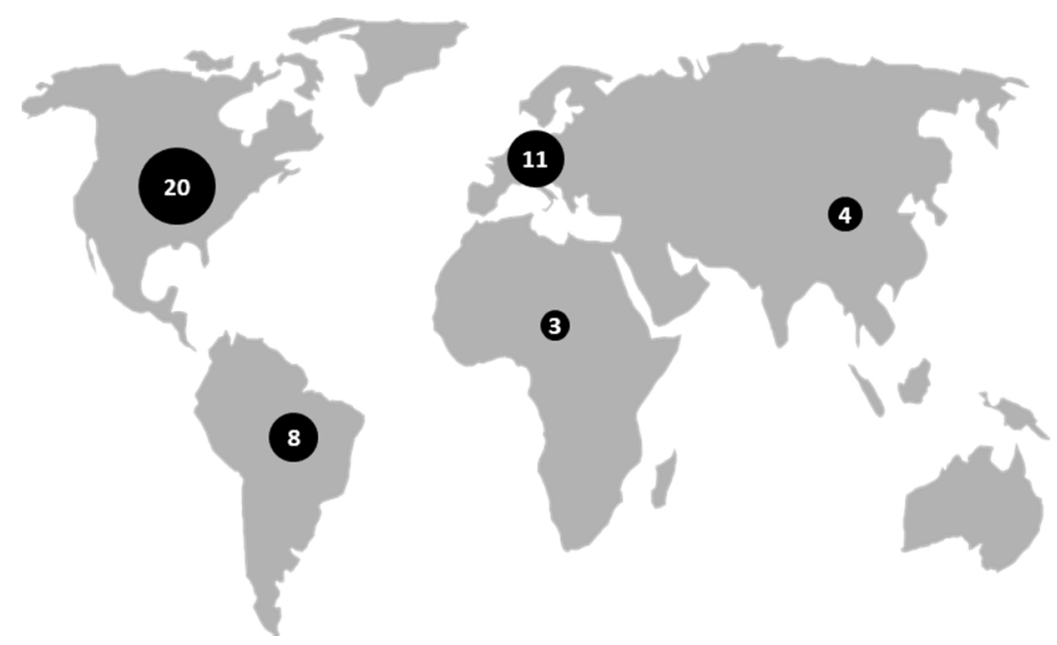

Figure 1. Number of studies by region. 
Table 1. Characteristics of datasets.

\begin{tabular}{|c|c|c|c|c|c|c|c|}
\hline Reference & Country & Years & Periodicity & Type of Data & Sample & $\begin{array}{l}\text { Sector (Number of } \\
\text { Subsectors) }\end{array}$ & Water Input \\
\hline Angulo et al. (2014) & Spain & 1995-2006 & Annual & $\mathrm{MD} / \mathrm{PD}$ & 676 firms & Hotels and restaurants (3) & PS \\
\hline Arbués et al. (2010) & Spain & 1996-2000 & Quarterly & $\mathrm{MD} / \mathrm{PD}$ & 298 firms & $\mathrm{M}$ and $\mathrm{S}$ & PS \\
\hline Babin et al. (1982) & USA & 1973 & Annual & $\mathrm{MD} / \mathrm{CS}$ & 245 firms & M (6) & PS \\
\hline Bell and Griffin (2008) & USA & 1995-2005 & Monthly & $\mathrm{AD} / \mathrm{PD}$ & 210 cities & $M$ and $S(2)$ & PS \\
\hline Bruneau and Renzetti (2014) & Canada & $1986,1991,1996$ & Annual & $\mathrm{MD} / \mathrm{PD}$ & 2725 firms & $\mathrm{M}(12)$ & RW \\
\hline Bruneau et al. (2010) & Canada & 1996 & Annual & $\mathrm{MD} / \mathrm{CS}$ & 5532 firms & M (13) & RW \\
\hline Canizales and Bravo (2011) & Mexico & 2003,2008 & Annual & $\mathrm{AD} / \mathrm{CS}$ & 9 States & M (5) & PS \\
\hline Dachraoui and Harchaoui (2004) & Canada & $1981,1986,1991,1996$ & Annual & $\mathrm{AD} / \mathrm{PD}$ & 36 sectors & $\mathrm{M}, \mathrm{C}$, and S (36) & TI \\
\hline De Rooy (1974) & USA & 1965 & Annual & $\mathrm{MD} / \mathrm{CS}$ & 30 firms & Chemical & TI \\
\hline Deyà-Tortella et al. (2016) & Spain & 2007 & Annual & $\mathrm{MD} / \mathrm{CS}$ & 134 firms & Hotels & PS \\
\hline Dupont and Renzetti (1998) & Canada & 1991 & Annual & $\mathrm{MD} / \mathrm{CS}$ & 88 firms & Food (3) & TI, RW, WW \\
\hline Dupont and Renzetti (2001) & Canada & 1981, 1986, 1991 & Annual & $\mathrm{AD} / \mathrm{PD}$ & $\begin{array}{l}58 \text { observations } \\
\text { (sector-region) }\end{array}$ & $\mathrm{M}$ & PS, RW \\
\hline Féres et al. (2012) & Brazil & 2002 & Annual & $\mathrm{MD} / \mathrm{CS}$ & 447 firms & M (6) & RW \\
\hline Féres and Reynaud (2005) & Brazil & 1999 & Annual & $\mathrm{MD} / \mathrm{CS}$ & 404 firms & $\mathrm{M}$ & TI, WW \\
\hline García-Valiñas (2005) & Spain & 1994-2000 & Quarterly & $\mathrm{MD} / \mathrm{PD}$ & 80 firms & M and S (3) & PS \\
\hline Gómez-Ugalde et al. (2012) & Mexico & 2000-2009 & Bimonthly & $\mathrm{AD} / \mathrm{TS}$ & Service sector & $\mathrm{S}$ & PS \\
\hline Gracia-de-Rentería et al. (2019) & Spain & 1993-2013 & Annual & $\mathrm{AD} / \mathrm{PD}$ & $\begin{array}{l}187 \text { observations } \\
\text { (sector-region) }\end{array}$ & M (11) & PS \\
\hline Gracia-de-Rentería et al. (2020) & Spain & 2012 & Annual & $\mathrm{MD} / \mathrm{CS}$ & 2579 firms & M and S (2) & SS \\
\hline Grebenstein and Field (1979) & USA & 1973 & Annual & $\mathrm{AD} / \mathrm{CS}$ & $\begin{array}{l}\text { All SIC two-digit } \\
\text { sectors }\end{array}$ & M & PS \\
\hline Guerrero (2005) & Mexico & 1994 & Annual & $\mathrm{MD} / \mathrm{CS}$ & 500 firms & M & TI \\
\hline Hussain et al. (2002) & Sri Lanka & 1994-1998 & Monthly & $\mathrm{AD} / \mathrm{TS}$ & $\begin{array}{l}\text { Manufacturing and } \\
\text { commercial sectors }\end{array}$ & M and S (2) & PS \\
\hline Kumar (2006) & India & 1996-1999 & Annual & $\mathrm{MD} / \mathrm{PD}$ & 92 firms & $\mathrm{M}(9)$ & TI \\
\hline Linz and Tsegai (2009) & South Africa & 2004-2009 & Monthly & $\mathrm{MD} / \mathrm{TS}$ & 5 mines & Mining & TI \\
\hline Lynne (1977) & USA & 1975 & Annual & $\mathrm{MD} / \mathrm{CS}$ & 156 firms & $\begin{array}{l}\text { Retail trade and } \\
\text { accommodation (4) }\end{array}$ & PS \\
\hline Lynne et al. (1978) & USA & 1976 & Monthly & $\mathrm{MD} / \mathrm{CS}$ & 137-190 firms & $\begin{array}{l}\text { Retail trade and } \\
\text { accommodation (5) }\end{array}$ & PS \\
\hline Malla and Gopalakrishnan (1999) & USA & n.s. & Monthly & $\mathrm{MD} / \mathrm{PD}$ & 13 firms & $\begin{array}{l}\text { Energy, food, construction, } \\
\text { and retail trade (2) }\end{array}$ & $\mathrm{TI}$ \\
\hline Mitchell et al. (2000) & UK & 1974-1995 & Annual & $\mathrm{AD} / \mathrm{TS}$ & Non-domestic sector & Non-domestic sector & PS \\
\hline Moeltner and Stoddard (2004) & USA & 1993-2000 & Monthly & $\mathrm{MD} / \mathrm{PD}$ & 348 firms & $S(5)$ & PS \\
\hline Nahman and De Lange (2012) & South Africa & 2011 & Annual & $\mathrm{MD} / \mathrm{CS}$ & 58 firms & M (12) & $\mathrm{TI}$ \\
\hline Onjala (2001) & Kenia & 1990-2000 & Monthly & $\mathrm{MD} / \mathrm{PD}$ & 51 firms & $M(3)$ & TI \\
\hline Renzetti (1988) & Canada & 1981 & Annual & $\mathrm{MD} / \mathrm{CS}$ & 372 firms & M (4) & TI, RW, WW \\
\hline Renzetti (1992) & Canada & 1985 & Annual & $\mathrm{MD} / \mathrm{CS}$ & 2000 firms & $\mathrm{M}(7)$ & TI, RW, WW \\
\hline Renzetti (1993) & Canada & 1985 & Annual & $\mathrm{MD} / \mathrm{CS}$ & 2000 firms & $\mathrm{M}(6)$ & PS, SS \\
\hline
\end{tabular}


Table 1. Cont.

\begin{tabular}{|c|c|c|c|c|c|c|c|}
\hline Reference & Country & Years & Periodicity & Type of Data & Sample & $\begin{array}{c}\text { Sector (Number of } \\
\text { Subsectors) }\end{array}$ & Water Input \\
\hline Revollo-Fernández et al. (2020) & Mexico & 2013 & Annual & $\mathrm{AD} / \mathrm{CS}$ & $\begin{array}{c}895 \text { observations } \\
\text { (sector-region) }\end{array}$ & M (15) & TI \\
\hline Reynaud (2003) & France & 1994-1996 & Annual & $\mathrm{MD} / \mathrm{PD}$ & 51 firms & M and S (8) & PS, SS, WW \\
\hline Scheider and Whitlatch (1991) & USA & 1959-1977 & Annual & $\mathrm{MD} / \mathrm{PD}$ & 6 firms & $M$ and $S(2)$ & PS \\
\hline Stone and Whittington (1984) & Netherlands & 1974 & Annual & $\mathrm{MD} / \mathrm{CS}$ & 21 firms & Paper & TI \\
\hline Tobarra-González (2018) & Chile & 2012 & Annual & $\mathrm{MD} / \mathrm{CS}$ & 2339 firms & $M(6)$ & TI \\
\hline Turnovsky (1969) & USA & 1962,1965 & Annual & $\mathrm{AD} / \mathrm{CS}$ & 19 cities & $\mathrm{M}$ & PS \\
\hline Vallés and Zárate (2013) & Spain & $2002-2003$ & Annual & $\mathrm{MD} / \mathrm{PD}$ & 87 firms & $M$ and S (10) & PS \\
\hline Vásquez-Lavín et al. (2020) & Chile & $1995-2014$ & Annual & $\mathrm{MD} / \mathrm{PD}$ & 10,528 firms & M (19) & TI \\
\hline Wang and Lall (2002) & China & 1993 & Annual & $\mathrm{MD} / \mathrm{CS}$ & 2000 firms & M (16) & TI \\
\hline Williams and Suh (1986) & USA & 1976 & Annual & $\mathrm{AD} / \mathrm{CS}$ & $125-140$ cities & $M$ and $S$ & PS \\
\hline Zhou and Tol (2005) & China & $1997-2003$ & Annual & $\mathrm{AD} / \mathrm{PD}$ & 31 regions & $\mathrm{M}$ & TI \\
\hline Ziegler and Bell (1984) & USA & n.s. & Annual & $\mathrm{MD} / \mathrm{CS}$ & 23 firms & Chemical and paper & TI \\
\hline
\end{tabular}

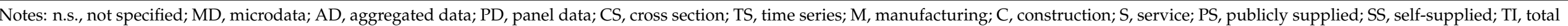
intake; RW, recirculated water; WW, wastewater. 
It is also rather common for these works to have only information on a single year or on a small number of years and usually annual data due to the difficulty in having data with a greater frequency (monthly or quarterly). The seminal works of the seventies used aggregate data, such as water consumption of the industrial sector. Subsequently, studies have been incorporating an increasingly high level of disaggregation, finally leading to the use of microdata for analysing firm's behaviour e.g., [30,36,38,41,55-59], which is the most suitable approach for this type of analysis for avoiding a possible aggregation bias due to the firms' heterogeneity. These microdata usually come (in a similar proportion) from public industrial surveys or from private surveys to firms elaborated by the own researchers, and, to a lesser extent, from metering records from the water utilities. However, due to information constrains, the number of observations per period (sample) is not usually very large, especially when private surveys are used (having, in this case, an average sample of 69 firms in contrast with the 2266 and 1632 firms in average when public surveys and metering records are used, respectively), and many papers give up on the use of microdata (Table 1). In this latter case, they used data aggregated by industrial activities [18,33], by geographical areas [17,60-62], or by activities and geographical areas at the same time $[35,37,39]$, and data mainly comes from official statistics.

The type of data available has led to propose cross-sectional studies, or panel data studies, but for a short period of time (Table 1). There is a lack of panel data analysis covering a wide time period $[30,35,36,38,61,63,64]$, which is the most adequate approach for capturing at the same time the individual and temporal dimension, and also few studies carried out time-series analysis $[26,29,65,66]$.

Figure 2 shows the percentage of studies using the different types of data. A total of $71 \%$ of the studies reviewed used microdata, although most of them only have information for one year ( $41 \%$ of studies used cross-sectional microdata). When aggregated data are used, both cross-sectional and panel studies are carried out in the same proportion. Figure 2 also reveals the few number of studies developing a time-series analysis (9\%).
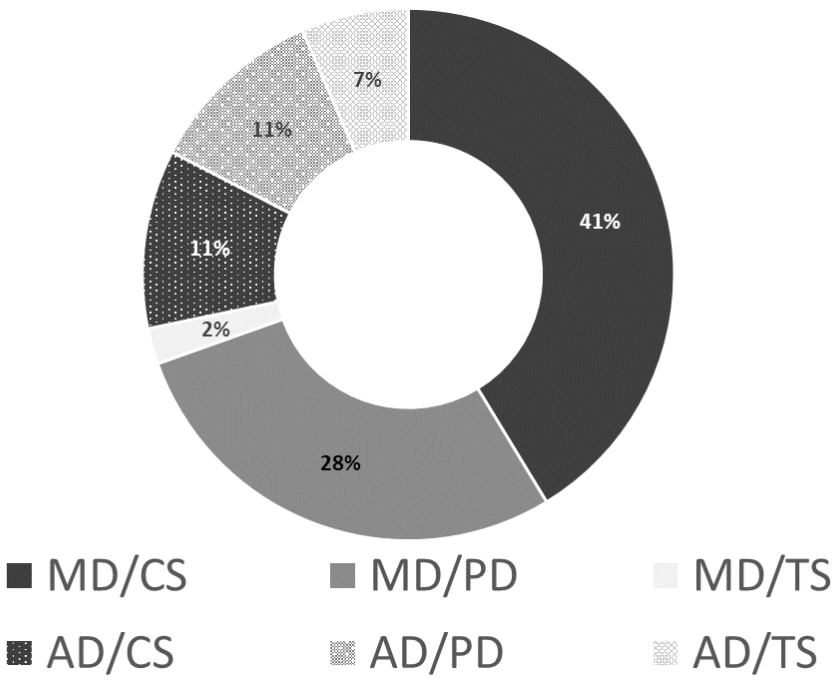

Figure 2. Percentage of studies by type of data. Note: MD, microdata; AD, aggregated data; CS, cross-section; PD, panel data; TS, time series.

Regarding the sectoral coverage of data, some authors analysed the demand for water in a specific industrial activity $[23,24,26,30,31,47,67]$. As seen in Table 1 and Figure 3, most studies focus only on the manufacturing industry (49 studies) without considering other industrial activities of great relevance (such as energy or mining), and few studies considered the service industry (19 studies) or the construction activities (4 studies). 


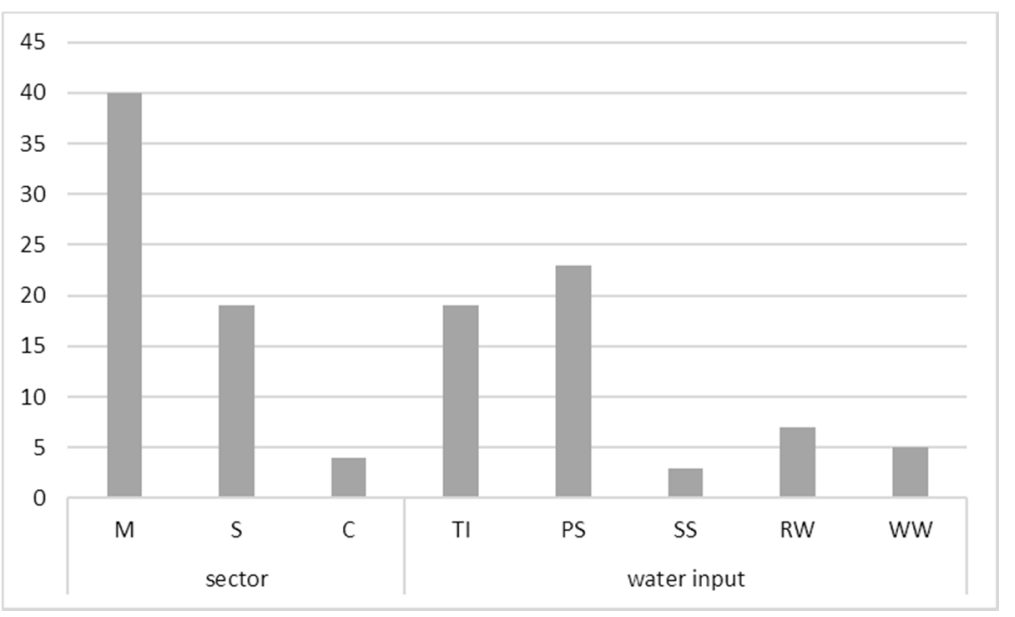

Figure 3. Number of studies by sector and water input. Note: $M$, manufacturing; S, service; C, construction; TI, total intake; PS, publicly supplied; SS, self-supplied; RW, recirculated water; WW, wastewater.

As seen in Table 1 and Figure 3, most studies do not have information on the volume of self-supplied or recirculated by companies (only three and seven studies have information on these water inputs, respectively), having only records of the volume of water collected from the public supply network (23 studies) or the total volume of intake water (as the sum of publicly and self-supplied water) (19 studies). The avoidance of other alternative sources to the public network could lead to significant errors in the estimation process, since many companies use several water sources simultaneously and, in some of them, recirculated water and, specially, self-supplied water represent a large share of total water use.

Data constrains also affect information on other inputs of the production process, so many papers have to exclude from the analysis some of the production inputs, or they have to consider that water demand only depends on its price and the level of activity. Moreover, the lack of accurate information also affects the way in which the variables of the model are specified. Table 2 collects all the variables that are usually considered in this sort of analysis along with the specification used in each case.

For all the variables, several specifications are used in the literature depending on the methodological approach used and the information available in each study. One of the variables with a more controversial specification is the price of water, which, due to its relevance, will be addressed separately in the next section. The specification of the price of capital is also especially problematic, which has led to several approaches, including the service price of capital [68], the implicit rental price of capital [69], or the weighted average cost of capital [30]. The specification of the output differs widely depending on the information available so that although most papers have information about the value of production or the firm's revenue, some papers have to use output proxies, such as the labour force $[25,29,48,50,52,65]$, the fiscal category of the street were the firm is located [70], or regional proxies, such as the GDP, GDP per capita, production index, or value added $[17,59,60,62,63]$. 
Table 2. Specification of variables.

\begin{tabular}{|c|c|c|}
\hline Variable & Specification & References \\
\hline \multirow{6}{*}{ Cost or quantity of capital } & Value of capital services & $\begin{array}{l}\text { Babin et al. (1982), Dachraoui and Harchaoui (2004), Grebenstein and } \\
\text { Field (1979) }\end{array}$ \\
\hline & Value of fixed assets & $\begin{array}{c}\text { Nahman and De Lange (2012), Revollo-Fernández et al. (2020), Vallés } \\
\text { and Zárate (2013), Wang and Lall (2002) }\end{array}$ \\
\hline & Stock of capital & $\begin{array}{c}\text { Gracia-de-Rentería et al. (2019), Kumar (2006), Tobarra-González (2018), } \\
\text { Vásquez-Lavín et al. (2020) }\end{array}$ \\
\hline & FCGF & Canizales and Bravo (2011) \\
\hline & Equity and debt costs & Angulo et al. (2014), Gracia-de-Rentería et al. (2021) \\
\hline & Financial costs & Feres and Reynaud (2005), Linz and Tsegai (2009) \\
\hline \multirow{5}{*}{ Price of capital } & Service price of capital & $\begin{array}{l}\text { Babin et al. (1982), Gracia-de-Rentería et al. (2019), Grebenstein and } \\
\text { Field (1979) }\end{array}$ \\
\hline & $\begin{array}{l}\text { Implicit rental price of } \\
\text { capital }\end{array}$ & Dachraoui and Harchaoui (2004), Dupont and Renzetti (2001) \\
\hline & Interest rate + depreciation rate & Feres et al. (2012), Feres and Reynaud (2005) \\
\hline & Weighted average cost of capital & Angulo et al. (2014), Gracia-de-Rentería et al. (2021) \\
\hline & Cost of capital per output unit & Linz and Tsegai (2009) \\
\hline \multirow[t]{2}{*}{ Cost or quantity of labour } & Staff expenditure & $\begin{array}{l}\text { Angulo et al. (2014), Babin et al. (1982), Dachraoui and Harchaoui } \\
\text { (2004), Dupont and Renzetti (2001), Feres and Reynaud (2005), } \\
\text { Gracia-de-Rentería et al. (2019, 2021), Grebenstein and Field (1979), } \\
\text { Guerrero (2005), Kumar (2006), Linz and Tsegai (2009), Reynaud (2003) }\end{array}$ \\
\hline & Number of employees & $\begin{array}{l}\text { Arbués et al. (2010), Canizales and Bravo (2011), Nahman and De Lange } \\
\text { (2012), Revollo-Fernández et al. (2020), Tobarra-González (2018), } \\
\text { Vásquez-Lavín et al. (2020), Wang and Lall (2002) }\end{array}$ \\
\hline Price of labour & Average price & $\begin{array}{l}\text { Angulo et al. (2014), Babin et al. (1982), Dachraoui and Harchaoui } \\
\text { (2004), Dupont and Renzetti (2001), Feres and Reynaud (2005), } \\
\text { Gracia-de-Rentería et al. (2019, 2021), Grebenstein and Field (1979), } \\
\text { Guerrero (2005), Linz and Tsegai (2009), Reynaud (2003), Vallés and } \\
\text { Zárate (2013) }\end{array}$ \\
\hline \multirow[t]{2}{*}{ Cost or quantity of energy } & $\begin{array}{l}\text { Expenditure on different energy } \\
\text { sources }\end{array}$ & $\begin{array}{l}\text { Canizales and Bravo (2011), Dupont and Renzetti (2001), Feres and } \\
\text { Reynaud (2005), Gracia-de-Rentería et al. (2019), Tobarra-González } \\
\text { (2018), Vásquez-Lavín et al. (2020) }\end{array}$ \\
\hline & Energy consumption & Nahman and De Lange (2012) \\
\hline \multirow[b]{2}{*}{ Price of energy } & Average price & Feres et al. (2012), Gómez-Ugalde et al. (2012) \\
\hline & $\begin{array}{l}\text { Weighted average price of } \\
\text { different energy sources }\end{array}$ & $\begin{array}{l}\text { Dupont and Renzetti (2001), Feres and Reynaud (2005), } \\
\text { Gracia-de-Rentería et al. (2019), Linz and Tsegai (2009) }\end{array}$ \\
\hline \multirow[t]{2}{*}{ Cost or quantity of supplies } & Supplies expenditure & $\begin{array}{l}\text { Angulo et al. (2014), Dachraoui and Harchaoui (2004), Dupont and } \\
\text { Renzetti (2001), Feres and Reynaud (2005), Gracia-de-Rentería et al. } \\
\text { (2019, 2021), Guerrero (2005), Revollo-Fernández et al. (2020), } \\
\text { Tobarra-González (2018), Vallés and Zárate (2013), Vásquez-Lavín et al. } \\
\text { (2020) }\end{array}$ \\
\hline & Value of intermediate goods & Canizales and Bravo (2011), Kumar (2006) \\
\hline \multirow{3}{*}{ Price of supplies } & Price index & $\begin{array}{l}\text { Dachraoui and Harchaoui (2004), Dupont and Renzetti (2001), Feres and } \\
\text { Reynaud (2005) }\end{array}$ \\
\hline & $\begin{array}{c}\text { Supplies expenditure per output } \\
\text { unit }\end{array}$ & Guerrero (2005) \\
\hline & Treated as unobservable & Angulo et al. (2014), Gracia-de-Rentería et al. $(2019,2021)$ \\
\hline
\end{tabular}


Table 2. Cont.

\begin{tabular}{|c|c|c|}
\hline Variable & Specification & References \\
\hline \multirow{5}{*}{ Output } & $\begin{array}{l}\text { Value of production or } \\
\text { revenue firms }\end{array}$ & $\begin{array}{l}\text { Angulo et al. (2014), Dupont and Renzetti (1998, 2001), Feres et al. } \\
\text { (2012), Feres and Reynaud (2005), Gracia-de-Rentería et al. (2019, 2020, } \\
\text { 2021), Kumar (2006), Renzetti (1992,1993), Revollo-Fernández et al. } \\
\text { (2020), Reynaud (2003), Tobarra-González (2018), Vallés and Zárate } \\
\text { (2013), Vásquez-Lavín et al. (2020), Wang and Lall (2002), Williams and } \\
\text { Suh (1986) }\end{array}$ \\
\hline & Output quantity & Guerrero (2005), Linz and Tsegai (2009) \\
\hline & Labour force & $\begin{array}{l}\text { Bruneau and Renzetti (2014), Bruneau et al. (2010), Hussain et al. (2002), } \\
\text { Malla and Gopalakrishnan (1999), Mitchell et al. (2000), Renzetti (1988) }\end{array}$ \\
\hline & Fiscal category of the street & García Valiñas (2005) \\
\hline & Other regional proxies & $\begin{array}{c}\text { Arbués et al. (2010), Canizales and Bravo (2011), Scheider and Whitlatch } \\
\text { (1991), Turnovsky (1969), Zhou and Tol (2005) }\end{array}$ \\
\hline \multirow{4}{*}{ Price of water } & Marginal price & $\begin{array}{l}\text { Bruneau and Renzetti (2014), Bruneau et al. (2010), Deyà-Tortella et al. } \\
\text { (2016), Dupont and Renzetti (1998, 2001), Gracia-de-Rentería et al. } \\
\text { (2021), Lynne (1977), Lynne et al. (1978), Moeltner and Stoddard (2004), } \\
\text { Onjala (2001), Renzetti (1988, 1992, 1993), Scheider and Whitlatch (1991), } \\
\text { Vallés and Zárate (2013), Williams and Suh (1986), Ziegler and Bell } \\
\text { (1984) }\end{array}$ \\
\hline & Average price & $\begin{array}{l}\text { Angulo et al. (2014), Babin et al. (1982), Deyà-Tortella et al. (2016), De } \\
\text { Rooy (1974), Feres et al. (2012), Feres and Reynaud (2005), García } \\
\text { Valiñas (2005), Gómez-Ugalde et al. (2012), Gracia-de-Rentería et al. } \\
\text { (2019, 2020, 2021), Grebenstein and Field (1979), Guerrero (2005), } \\
\text { Hussain et al. (2002), Linz and Tsegai (2009), Malla and Gopalakrishnan } \\
\text { (1999), Mitchell et al. (2000), Renzetti (1988), Reynaud (2003), Stone and } \\
\text { Whittington (1984), Turnovsky (1969), Vallés and Zárate (2013), } \\
\text { Williams and Suh (1986), Ziegler and Bell (1984), Zhou and Tol (2005) }\end{array}$ \\
\hline & Perceived price & Arbués et al. (2010) \\
\hline & Shadow price & $\begin{array}{l}\text { Kumar (2006), Nahman and De Lange (2012), Revollo-Fernández et al. } \\
\text { (2020), Tobarra-González (2018), Vásquez-Lavín et al. (2020), Wang and } \\
\text { Lall (2002) }\end{array}$ \\
\hline
\end{tabular}

\subsection{Specification of Water Price}

Traditionally, one of the main aims of the literature focused on water demand was to know the effect that a change in the water price may have on the demand for water. However, the specification of the price of water is not obvious at all. To advance in this issue, it is necessary to know the tariff structure associated with the water supply and sanitation service.

In practice, there are many rate structures [71], such as a flat rate independent of the level of consumption, a flat rate that allows a certain level of consumption plus an additional fee for excessive consumption or a two-part rate that includes a fixed fee (for service access) and a variable fee (which depends on the volume of water). In the latter case, the variable fee can be based on different schemes: a uniform volumetric rate in which all the consumption units are taxed at the same price; an average price rate where the variable quota is obtained by multiplying the amount of water consumed by a price that varies according to the level of consumption (all consumption units being taxed at the same price); or a block rate where the variable quota is obtained by applying different prices to different consumption blocks. This latter rate can be based on increasing blocks (a higher price is applied to additional consumption units) or decreasing blocks (a lower price is applied to them).

Moreover, it is increasingly common to introduce a sanitation rate separated from the supply rate. Although most OECD countries apply the same type of rate for both concepts (usually combining a fixed and a variable fee), the price level and the number of blocks (in case of a block rate) usually varies in both rates [71]. Finally, in many countries, additional water taxes are being introduced with an ecological purpose to contribute to the reduction of water pollution. 
The diversity and complexity of tariff structures make the specification of the price of water a key aspect when addressing the estimation of water demand. Therefore, this issue has been the subject of an intense methodological debate but more focused on the domestic sphere, e.g. [72-81], than on industrial water [23,36,42,82]. Some works have also conducted this debate in other sectors, such as electricity [83-85] or natural gas [86].

When users face uniform rates in which all consumption units are taxed at the same price, there is no difference between the average and the marginal price. However, when users face discontinuous rates (which include a fixed and a variable fee or introduce a block rate system), this equality is broken. In this case, the use of the marginal price is more adequate, theoretically, since it informs about the cost of using an additional unit of water. However, most users are uninformed about the concept of marginal price, which, together with the complexity of water tariffs and the difficulty of understanding the invoices, bring the assumption of perfect information into question. Therefore, users can react to the marginal price, to the average price, or to a perceive price between them.

However, in the industrial sphere, the assumption of perfect information may be more defensible than in the domestic one, since, as pointed out by Opaluch (1982) and Nieswiadomy and Molina (1991), the information costs are lower for large consumers, so they are more likely to react to the marginal price since they could obtain a greater benefit if they try to understand the tariff structure and introduce it into their decisions $[75,76]$.

An alternative to the use of a single price variable (average or marginal) is that one proposed by Shin (1985) for the case of electricity, which consists of using a perceived price variable as a function of the average price, the marginal price, and a price perception parameter [85]. This approach has been mostly used in the electricity sector, e.g. [87,88], but it has also been adapted to the case of industrial water demand [59] and domestic water demand, e.g. [89-91]. This exercise, which is relatively standard in econometric terms when a simplified demand function is specified, can become very complex when the interactions between variables are multiplied, as in the case of the translog cost and production functions.

The diversity of arguments regarding the specification of the price of water imply that, as shown in Table 2, empirical studies on industrial water demand used both the average and the marginal price. This choice has depended on the consideration of the assumption of perfect information, on the type of water tariff applied, and on data constrains, since most researchers do not usually have information on the marginal price.

The decision about the price specification is relevant since it can condition the results obtained. However, as aforementioned, this hard discussion is particularly difficult to solve. The alternative that has been consolidated in the applied literature is to solve the dilemma as a problem of model selection that can be addressed by using standard techniques to compare non-nested models, such as the J test or the information criteria.

Empirical evidence regarding this issue in the industrial sphere provides evidence in favour of using both the marginal price [55,82] and the average price [23]. The same happens in the domestic context, with some papers concluding the suitability of using the marginal price, e.g. $[72,76,78,81]$, and others the average one, e.g. [74,83,90,92], so the debate remains still open.

\subsection{The Estimated Function}

One of the main differences between the literature dedicated to water for industrial uses and that aimed at domestic uses is that, for the latter, water is a final consumption good whose demand is derived from a utility function, while for the industry, water is an input used in the production process that must be incorporated into the corresponding production function. For this purpose, information on the level of production and the quantity used of each of the inputs is needed (see Equation (2)).

However, the direct estimation of the production function is not operational for estimating the determinants of water demand, as reflected by its scarce use in the literature (see Table 3) by only a few studies focused on estimating water shadow prices that, to achieve 
this objective, also calculate water demand elasticities. On the contrary, the most popular approach in this literature is to estimate the cost function (see Table 3), which is immediately derived from the production function considering the input prices as exogenous and for a given output level. Its estimation requires information on the price of the inputs and on the cost that each of them represents as well as on the level of output (see Equation (3)).

In the sphere of the cost function, some authors have addressed the distinction between the short and long term, based on the traditional microeconomic theory. That is, in the long term, firms have full decision-making capacity regarding the use of the inputs, so all the productive factors are variable. But, in the short term, the technology is given and some inputs could be fixed, so firms have little or no capacity to decide on its use. Few authors have considered this dilemma as a decision problem. Among them, Dupont and Renzetti (2001) concluded that water is a variable input in the industry [39], while Angulo et al. (2014) obtained that it is a quasi-fixed input in the hotel, bar, and restaurant sector [30]. In both cases, the discussion is resolved in terms of a battery of $\mathrm{J}$ tests that compares non-nested models. Nevertheless, in most papers, authors directly assume the quasi-fixed nature of the water input, as in Dachraoui and Harchaoui (2004) [33].

In a context of cost minimization, the Shepard's lemma allows to obtain the conditional input demand functions as the derivate of the cost function with respect to the factor price. Thus, the quantity demanded of each input depends on its own price, the price of the other inputs, and the level of production (see Equation (4)). This approach allows calculation of the elasticity of the demand for water with respect to the price of the resource (direct price elasticity) and with respect to the level of production (output elasticity) as well as to analyse the substitutability or complementarity relationships between the different inputs.

However, as aforementioned, the lack of information on some of the inputs is rather common. In most of these cases, authors have opted for the assumption of separability of inputs [93] to overcome this limitation, as in $[24,48,49,54,64]$. The results are obviously simplified, since water demand depends only on its own price and the level of activity. However, this hypothesis, due to its strong implications, should be tested before being considered, something that, as far as we know, only Reynaud (2003) has raised [54]. Other works have opted for a lower level of formalization, supplying the lack of information with the imposition of simplified demand functions according to the existing tradition in the field of water demand for domestic uses in which the amount of water demand depends on its price and the level of activity (see Equation (1)). As shown in Table 3, this approach has been widely used, although it is hardly justifiable in the sphere of production in which several inputs interact with each other.

Another issue that require further advances is that one related to the functional form, since the literature has usually imposed a clearly parametric solution by considering a limited number of functions that the authors assume a priori. One of the most used specifications in this literature is the translog function because of its flexibility, parsimony, and homogeneity in prices [94], although the lineal or the double logarithmic functions have been also widely used (see Table 3).

In this field, the most worrisome issues are the lack of application of essential specification tests related to the functional form, such as the RESET test or the likelihood ratio test (some exceptions are $[35,36]$ ), and the omission of more flexible techniques (such as the Box-Cox approach) to better deal with the problem of the functional form. In a more general context, the problem of the (potential) nonlinearity of production technology should be pointed out. The functional forms usually used in this literature are characterized by being linearizable, leaving out other alternatives, such as the VES function [95] and other more general ones $[96,97]$. One should not forget that, in the last decades, a relevant econometric analysis dedicated to non-parametric methods has been developed to avoid, precisely, the assumption of excessively restrictive hypotheses and with insufficiently empirical evidence. 
Table 3. Estimated function and methodology.

\begin{tabular}{|c|c|c|c|c|c|}
\hline Function & Functional Form & $\begin{array}{l}\text { Estimation } \\
\text { Techniques }\end{array}$ & Reference & Endogeneity & $\begin{array}{c}\text { Sectoral } \\
\text { Heterogeneity }\end{array}$ \\
\hline \multirow{7}{*}{$\begin{array}{l}\text { Production } \\
\text { function }\end{array}$} & \multirow{7}{*}{ Translog } & $\mathrm{LP}$ & Kumar (2006) & - & $\mathrm{D}$ \\
\hline & & \multirow{3}{*}{ n.s. } & Revollo-Fernández et al. (2020) & - & $\mathrm{S}$ \\
\hline & & & Vásquez-Lavín et al. (2020) & - & $S$ \\
\hline & & & Wang and Lall (2002) & - & $\mathrm{D}$ \\
\hline & & \multirow{3}{*}{ OLS } & Cañizales and Bravo (2011) & - & - \\
\hline & & & Nahman and De Lange (2012) & - & $S$ \\
\hline & & & Tobarra-González (2018) & - & $\mathrm{S}$ \\
\hline \multirow{15}{*}{ Cost function } & \multirow{13}{*}{ Translog } & \multirow{10}{*}{ SUR } & Angulo et al. (2014) & Lagged price & $S$ \\
\hline & & & Babin et al. (1982) & & $\mathrm{S}$ \\
\hline & & & Dachraoui and Harchaoui (2004) & Lagged price & $\mathrm{D}$ \\
\hline & & & Dupont and Renzetti (2001) & IV & - \\
\hline & & & Feres and Reynaud (2005) & - & $\mathrm{D}$ \\
\hline & & & Gracia-de-Rentería et al. (2019) & Lagged price & $S$ \\
\hline & & & Gracia-de-Rentería et al. (2021) & Lagged price & $\mathrm{S}$ \\
\hline & & & Grebenstein and Field (1979) & -1 & - \\
\hline & & & Guerrero (2005) & - & $S$ \\
\hline & & & Linz and Tsegai (2009) & - & - \\
\hline & & FGLS & Reynaud (2003) & - & - \\
\hline & & \multirow{2}{*}{ 3SLS } & Dupont and Renzetti (1998) & - & - \\
\hline & & & Renzetti (1992) & IV & $\mathrm{S}$ \\
\hline & \multirow{2}{*}{$\begin{array}{l}\text { Cobb- } \\
\text { Douglas }\end{array}$} & 2SLS & Renzetti (1988) & IV & $S$ \\
\hline & & 3SLS & Onjala (2001) & IV & S \\
\hline \multirow{24}{*}{$\begin{array}{l}\text { Demand } \\
\text { function }\end{array}$} & - & $\begin{array}{l}\text { Quantile } \\
\text { regression }\end{array}$ & Deyà-Tortella et al. (2016) & $\begin{array}{c}\text { Difference } \\
\text { variable }\end{array}$ & Q \\
\hline & Exponential & OLS & Ziegler and Bell (1984) & - & $\mathrm{D}$ \\
\hline & \multirow{8}{*}{ Lineal } & \multirow{2}{*}{ 2SLS } & Bruneau and Renzetti (2014) & IV & $\mathrm{D}$ \\
\hline & & & Bruneau et al. (2010) & IV & $\mathrm{D}$ \\
\hline & & GLS & Scheider and Whitlatch (1991) & - & - \\
\hline & & GMM & García Valiñas (2005) & - & $\mathrm{D}$ \\
\hline & & n.s. & Mitchell et al. (2000) & - & - \\
\hline & & \multirow{2}{*}{ OLS } & Gómez-Ugalde et al. (2012) & - & - \\
\hline & & & Stone and Whittington (1984) & - & - \\
\hline & & OLS and GLS & Malla and Gopalakrishnan (1999) & - & $\mathrm{D}$ \\
\hline & \multirow{4}{*}{ Log-lineal } & 2GLS & Moeltner and Stoddard (2004) & IV & $\mathrm{S}$ \\
\hline & & \multirow{2}{*}{ n.s. } & Lynne (1977) & - & $\mathrm{S}$ \\
\hline & & & Lynne et al. (1978) & - & S \\
\hline & & OLS & Williams and Suh (1986) & - & - \\
\hline & \multirow{8}{*}{ Log-log } & 2SGMM & Arbués et al. (2010) & - & $\mathrm{D}$ \\
\hline & & \multirow{2}{*}{ FGLS } & Vallés and Zárate (2013) & - & $\mathrm{D}$ \\
\hline & & & Zhou and Tol (2005) & - & - \\
\hline & & ML & Renzetti (1993) & IV & $\mathrm{S}$ \\
\hline & & \multirow{4}{*}{ OLS } & De Rooy (1974) & - & - \\
\hline & & & Feres et al. (2012) & - & $\mathrm{D}$ \\
\hline & & & Gracia-de-Rentería et al. (2020) & - & $\mathrm{D}$ \\
\hline & & & Turnovsky (1969) & - & - \\
\hline & $\begin{array}{l}\text { Linear and } \\
\text { log-log }\end{array}$ & GLS & Hussain et al. (2002) & - & - \\
\hline & Square roots & GLS & Bell and Griffin (2008) & IV & - \\
\hline
\end{tabular}

Notes: n.s., not specified; OLS, ordinary least squares; GLS, generalised least squares FGLS, factible generalised least squares; LP, linear programming; ML, maximum likelihood; SUR, seemingly unrelated regression; GMM, generalised method of moments; IV, instrumental variables; $\mathrm{D}$, introduction of sectoral dummies; $\mathrm{S}$, estimation by sectors; $\mathrm{Q}$, quantile regressions. 


\subsection{Estimation Techniques}

Estimation techniques used in this literature were summarized in Table 3, which highlights the diversity of approaches employed. The choice of the estimation method is, in most cases, conditioned by two methodological issues: the election of the estimated function and the treatment of endogeneity.

The former is especially evident when cost-minimizing input demand functions are derived from the cost function. In this approach, which is highly suitable for capturing the economic context from which the demand for water comes from, a system of seemingly unrelated regressions (SUR) is estimated, where the variable explained in each equation is the cost share of the corresponding input. The works of Dupont and Renzetti (2001) and Féres and Reynaud (2005), among others, were key to establish this approach in the estimation of industrial water demand $[39,40]$. Angulo et al. (2014) and Gracia-deRentería et al. $(2019,2021)$ also included the cost function in the SURE for reasons of efficiency $[30,35,36]$.

The question of endogeneity is due to simultaneous causality between the volume of water demanded and the price of water. On the one hand, the use of the average price as a ratio between water expenditure and water consumption generates obvious problems of endogeneity. On the other hand, block rates, which are very popular nowadays, are also a source of problems because the marginal price depends on the amount of water consumed. The issue of endogeneity can be treated from two approaches. The dominant one in the literature is the use of instrumental variables as additional variables that introduced in the model, which are not relevant in the demand equation but closely related to the problematic variable (the price, in this case). This leads to a model of simultaneous equations in which one equation explains the amount of water demand and the second one is directed to price formation. The model can then be estimated by maximum likelihood methods or by more direct methods, such as two or three-stage least squares (2SLS or 3SLS), e.g. [24,48,49,52]. The alternatives to the use of instrumental variables are scarce, and the most common solution is to use the lagged price variable for which it is necessary to ensure that the error term of the equation does not have temporal dependence $[30,33,35,36]$. Nevertheless, despite the attention paid to this issue, many papers do not adopt measures to avoid endogeneity problems, which may lead to biased results.

The review of the literature on industrial water demand also reveals some issues that need to receive greater attention. One of those questions has to do with heterogeneity. Although most papers recognize the high sectoral heterogeneity in the use of water, the solutions proposed only include the incorporation of dummies or the estimation by sectors (see Table 3), whereas other alternatives, such as the quantile regressions, are omitted (see, as an exception, [31]). This contrasts with the popularity of this approach to estimate the demand of other commodities, such as electricity, or even for household water demand, e.g. $[98,99]$.

This also highlights the low dynamics incorporated in the models. Most papers use static specifications in which adjustments are supposed to be resolved instantaneously, since the only study in the industrial sphere in which a dynamic structure is introduced is Abués et al. (2010) [59]. This situation is surprising given the great importance of dynamic models in the contemporary applied research, especially considering that, in the studies of water demand in the domestic sphere, these models are abundant, e.g. [92,100,101]. Some of the reasons could be the interpretation of this type of models as equilibrium relationships (reason not necessarily acceptable), the low frequency of the data (in general, they are annual series, while in the field, domestic data abound infra-annual frequency data), or the problems to have long representative series.

Finally, the little attention paid to the study of the statistical properties of the series used to explain the demand for water is also worrisome. In fact, Gracia-de-Rentería et al. (2019) is the only study in the industrial sphere that performed a cointegration analysis of the series [35], whereas in the domestic field, we can cite more references [102-104]. This type of analysis should be carried out when using time series or panel data, as long- 
term equilibrium relationships are assumed. However, the sort size of the available series may hinder its accomplishment.

\section{Elasticities Obtained}

\subsection{Total Intake Water and Publicly Supplied Water}

Looking at the total intake water demand and the publicly supplied water demand, a negative direct price elasticity is usually observed (see Table 4), indicating that an increase in the price of water leads to a reduction of the amount of water demanded. Values range between -0.01 [42] and -3.0 [34], with a median value of -0.57 .

Table 4. Direct price and output elasticities of water.

\begin{tabular}{|c|c|c|c|c|c|c|}
\hline & \multirow{2}{*}{$\begin{array}{l}\text { Particularities of } \\
\text { Estimation }\end{array}$} & \multirow[b]{2}{*}{ Sector } & \multicolumn{2}{|c|}{ Price Elasticity } & \multicolumn{2}{|c|}{ Output Elasticity } \\
\hline & & & Average & $\begin{array}{l}\text { Sector with Max. } \\
\text { Value (Elasticity) }\end{array}$ & Average & $\begin{array}{l}\text { Sector with Max. } \\
\text { Value (Elasticity) }\end{array}$ \\
\hline \multicolumn{7}{|l|}{ Total intake water } \\
\hline \multirow{3}{*}{ De Rooy (1974) } & Refrigeration & \multirow{3}{*}{ Chemical } & -0.89 & - & 1.21 & - \\
\hline & $\begin{array}{c}\text { Incorporation to } \\
\text { product }\end{array}$ & & -0.35 & - & 1.36 & - \\
\hline & Steam generation & & -0.59 & - & 1.24 & - \\
\hline Dupont and Renzetti (1998) & & Food & -0.34 & Fruit $(-0.38)$ & 0.46 & Meat (0.50) \\
\hline Dupont and Renzetti (2001) & & M & -0.77 & - & 0.69 & - \\
\hline \multirow{2}{*}{ Féres et al. (2012) } & Recirculation & \multirow{2}{*}{ M } & -0.53 & - & 0.66 & - \\
\hline & No recirculation & & -0.23 & - & 0.53 & - \\
\hline Féres and Reynaud (2005) & & M & -1.08 & - & 0.91 & - \\
\hline Guerrero (2005) & & M & -0.30 & Beverage (-3.09) & - & - \\
\hline Kumar (2006) & & M & -1.1 & Leather $(-0.94)$ & - & - \\
\hline Linz and Tsegai (2009) & & Mining & -0.85 & - & - & - \\
\hline \multirow{2}{*}{$\begin{array}{l}\text { Malla and Gopalakrishnan } \\
\text { (1999) }\end{array}$} & OLS & \multirow{2}{*}{ I } & - & Food $\left(-0.90^{*}\right)$ & - & Other (2.55) \\
\hline & GLS & & - & Food $(-0.37)$ & - & Food $(0.25)$ \\
\hline Nahman and De Lange (2012) & & M & -3.0 & Paper $(-6.81)$ & - & - \\
\hline Onjala (2001) & & M & - & $\begin{array}{c}\text { Paper } \\
(-0.21 /-0.37)\end{array}$ & - & \\
\hline Renzetti (1988) & & M & $-0.54 /-0.12$ & Light industry & $1.94 / 0.69$ & Light industry \\
\hline Renzetti (1992) & & M & $-0.38 *$ & Paper $(-0.59)$ & - & - \\
\hline Revollo-Fernández et al. (2020) & & M & 0.06 & Chemistry $(0.21)$ & - & - \\
\hline Stone and Whittington (1984) & & Paper & -0.25 & - & - & - \\
\hline Tobarra-González (2018) & & M & -1.1 & Paper $(-3.17)$ & - & - \\
\hline Vásquez-Lavín et al. (2020) & & M & -1.23 & $\begin{array}{l}\text { Machinery } \\
(-1.50)\end{array}$ & - & - \\
\hline Wang and Lall (2002) & & M & -1.03 & Energy $(-1.20)$ & - & - \\
\hline Zhou and Tol (2005) & & M & -0.35 & - & -0.32 & - \\
\hline \multirow{2}{*}{ Ziegler and Bell (1984) } & APW & \multirow{2}{*}{$\begin{array}{c}\text { Chemical and } \\
\text { paper }\end{array}$} & -0.08 & - & - & - \\
\hline & MPW & & 0.00001 & - & - & - \\
\hline \multicolumn{7}{|l|}{ Publicly-supplied water } \\
\hline Angulo et al. (2014) & & $\begin{array}{l}\text { Hotels and } \\
\text { restaurants }\end{array}$ & $0.082 *$ & Hotels $(-0.37)$ & 0.398 & Hotels (0.64) \\
\hline \multirow{2}{*}{ Arbués et al. (2010) } & Short run & \multirow{2}{*}{ I } & -0.25 & & 0.195 & \\
\hline & Long run & & -0.57 & & 0.444 & \\
\hline Babin et al. (1982) & & M & -0.56 & Paper $(-0.66)$ & - & - \\
\hline \multirow{4}{*}{ Bell and Griffin (2008) } & \multirow{2}{*}{ Short run } & M & $-0.08^{*}$ & - & - & - \\
\hline & & $\mathrm{S}$ & $-0.48^{*}$ & - & & - \\
\hline & \multirow{2}{*}{ Long run } & M & $0.31 *$ & - & - & - \\
\hline & & $S$ & -1.09 & - & - & - \\
\hline \multirow{2}{*}{ Canizales and Bravo (2011) } & Year 2003 & \multirow{2}{*}{ M } & -0.08 & Sugar $(-0.07)$ & - & - \\
\hline & Year 2008 & & -0.07 & Sugar $(-0.05)$ & - & - \\
\hline
\end{tabular}


Table 4. Cont.

\begin{tabular}{|c|c|c|c|c|c|c|}
\hline & \multirow{2}{*}{$\begin{array}{l}\text { Particularities of } \\
\text { Estimation }\end{array}$} & \multirow{2}{*}{ Sector } & \multicolumn{2}{|c|}{ Price Elasticity } & \multicolumn{2}{|c|}{ Output Elasticity } \\
\hline & & & Average & $\begin{array}{l}\text { Sector with Max. } \\
\text { Value (Elasticity) }\end{array}$ & Average & $\begin{array}{l}\text { Sector with Max. } \\
\text { Value (Elasticity) }\end{array}$ \\
\hline \multicolumn{7}{|l|}{ Publicly-supplied water } \\
\hline Deyà-Tortella et al. (2016) & & Hotels & $-0.02 *$ & - & - & - \\
\hline \multirow{2}{*}{ García-Valiñas (2005) } & Normal demand & \multirow{2}{*}{ I } & -0.12 & - & - & - \\
\hline & Peak demand & & -0.13 & - & - & - \\
\hline Gómez-Ugalde et al. (2012) & & S & -1.03 & - & 1.22 & - \\
\hline Gracia-de-Rentería et al. (2019) & & M & -0.66 & Food $(-1.69)$ & 1.07 & Other (1.52) \\
\hline \multirow{8}{*}{ Gracia-de-Rentería et al. (2021) } & \multirow{4}{*}{ APW } & I & -0.99 & - & 0.65 & - \\
\hline & & M & -0.94 & $\begin{array}{l}\text { Machinery } \\
(-1.22)\end{array}$ & 0.19 & Plastic (1.06) \\
\hline & & $\mathrm{C}$ & -0.93 & - & $-0.10^{*}$ & - \\
\hline & & $\mathrm{S}$ & -1.00 & $\begin{array}{c}\text { Professional } \\
\text { activities }(-1.08)\end{array}$ & 0.74 & Education (1.06) \\
\hline & \multirow{4}{*}{ MPW } & I & -0.86 & - & 0.73 & - \\
\hline & & M & -0.52 & Food $(-0.62)$ & $-0.37^{*}$ & Food (0.65) \\
\hline & & $\mathrm{C}$ & $-0.58^{*}$ & - & 2.85 & - \\
\hline & & $\mathrm{S}$ & -0.88 & $\begin{array}{l}\text { Real estate } \\
(-1.24)\end{array}$ & 0.83 & Real estate (2.14) \\
\hline \multirow{2}{*}{ Grebenstein and Field (1979) } & AWWA data & \multirow{2}{*}{ M } & $-0.33^{*}$ & - & - & - \\
\hline & MM data & & -0.80 & - & - & - \\
\hline \multirow{4}{*}{ Hussain et al. (2002) } & \multirow{2}{*}{ Log-log } & M & -1.34 & - & $0.39 *$ & - \\
\hline & & $\mathrm{S}$ & -0.17 & - & 0.81 & - \\
\hline & \multirow{2}{*}{ Linear } & M & -1.15 & - & $0.34 *$ & - \\
\hline & & $\mathrm{S}$ & -0.17 & - & 0.80 & - \\
\hline Lynne (1977) & & $\mathrm{S}$ & - & $\begin{array}{c}\text { Department } \\
\text { stores }(-1.33)\end{array}$ & - & - \\
\hline Lynne et al. (1978) & & $\mathrm{S}$ & - & $\begin{array}{c}\text { Department } \\
\text { stores }(-1.07)\end{array}$ & - & - \\
\hline Mitchell et al. (2000) & & $\mathrm{I}$ & -0.92 & - & 2.85 & - \\
\hline Moeltner and Stoddard (2004) & & $\mathrm{S}$ & - & $\begin{array}{c}\text { Recreation } \\
\text { services }(-0.62)\end{array}$ & - & - \\
\hline Renzetti (1993) & & M & -0.75 & Food $(-2.17)$ & 0.76 & Food (0.74) \\
\hline \multirow{3}{*}{ Reynaud (2003) } & & I & -0.29 & - & 0.34 & - \\
\hline & & M & - & $\begin{array}{c}\text { Other } \\
\text { manufactures } \\
(-0.79)\end{array}$ & - & - \\
\hline & & $\mathrm{S}$ & -0.27 & - & - & - \\
\hline \multirow{4}{*}{ Scheider and Whitlatch (1991) } & \multirow{2}{*}{ Short run } & M & $-0.44 *$ & - & - & - \\
\hline & & $\mathrm{S}$ & -0.23 & - & - & - \\
\hline & \multirow{2}{*}{ Long run } & M & $-0.11 *$ & - & - & - \\
\hline & & $\mathrm{S}$ & -0.92 & - & - & - \\
\hline Turnovsky (1969) & & M & -0.5 & - & - & - \\
\hline \multirow[t]{2}{*}{ Vallés and Zárate (2013) } & APW & \multirow[t]{2}{*}{ I } & -0.01 & - & 0.301 & - \\
\hline & MPW & & -0.01 & - & 0.299 & - \\
\hline \multirow{10}{*}{ Williams and Suh (1986) } & APW & M & -0.73 & & 0.20 & \\
\hline & & S & -0.36 & & 0.17 & \\
\hline & MPW & $\mathrm{M}$ & -0.44 & & 0.18 & \\
\hline & & $\mathrm{S}$ & $-0.14^{*}$ & & 0.18 & \\
\hline & MTB1 & M & -0.72 & & 0.29 & \\
\hline & & $\mathrm{S}$ & $-0.23 *$ & & 0.20 & \\
\hline & MTB2 & M & -0.97 & & 0.27 & \\
\hline & & $S$ & -0.34 & & 0.20 & \\
\hline & МТB3 & $\mathrm{M}$ & -0.76 & & 0.30 & \\
\hline & & $\mathrm{S}$ & -0.31 & & 0.21 & \\
\hline
\end{tabular}


Table 4. Cont.

\begin{tabular}{|c|c|c|c|c|c|c|}
\hline & \multirow{2}{*}{$\begin{array}{l}\text { Particularities of } \\
\text { Estimation }\end{array}$} & \multirow{2}{*}{ Sector } & \multicolumn{2}{|c|}{ Price Elasticity } & \multicolumn{2}{|c|}{ Output Elasticity } \\
\hline & & & Average & $\begin{array}{l}\text { Sector with Max. } \\
\text { Value (Elasticity) }\end{array}$ & Average & $\begin{array}{l}\text { Sector with Max. } \\
\text { Value (Elasticity) }\end{array}$ \\
\hline \multicolumn{7}{|l|}{ Self-supplied water } \\
\hline Gracia-de-Rentería et al. (2020) & & M & -0.50 & & 0.38 & \\
\hline Renzetti (1993) & & $\mathrm{M}$ & -0.31 & Metal (-1.14) & 1.09 & Textile (1.14) \\
\hline \multirow{3}{*}{ Reynaud (2003) } & & I & $0.25 *$ & - & 0.58 & - \\
\hline & & M & - & $\begin{array}{l}\text { Chemical } \\
\left(-0.06^{*}\right)\end{array}$ & - & - \\
\hline & & $\mathrm{S}$ & $-0.05 *$ & - & - & - \\
\hline \multicolumn{7}{|l|}{ Recirculated water } \\
\hline Bruneau and Renzetti (2014) & & M & -0.24 & & 1.04 & \\
\hline Bruneau et al. (2010) & & M & -0.27 & & 0.3851 & \\
\hline Dupont and Renzetti (1998) & & Food & -0.82 & Meat $(-1.35)$ & 0.48 & Milk (0.47) \\
\hline Dupont and Renzetti (2001) & & M & $-0.69 *$ & & 0.72 & \\
\hline Renzetti (1988) & & M & - & $\begin{array}{l}\text { Light industry } \\
\quad(-0.77)\end{array}$ & - & Chemical (2.48) \\
\hline Renzetti (1992) & & M & -1.83 & Textile $(-1.48)$ & - & \\
\hline
\end{tabular}

Notes: APW, average price of water; MPW, marginal price of water; MTB, monthly typical bill; OLS, ordinary least squares, GLS, generalised least squares; $M$, manufacturing; $S$, service; I, industrial sector $(M+S)$; WW, wastewater. * Elasticity not significant at $5 \%$. In brackets, the maximum and minimum value by sector of activity.

However, the comparison of elasticities between different studies should be done with caution because the elasticities obtained vary significantly according to the nature of the data, the functional form, the specification of variables, the method of estimation, and other peculiarities of estimation. Of special interest are the differences obtained when the price elasticity is estimated using the average and the marginal price of water. Results reveal a higher elasticity when the average price is used $[23,36,82]$, which is also in line with the literature focused on domestic demand, e.g. [72,78,79].

One of the conclusions drawn from the results is that the water demand for industrial uses is inelastic (direct price elasticity usually less than the unit), although this elasticity is greater than in the domestic case. The inelasticity of the demand may be due to several reasons, such as the difficulty in finding water substitutes or that users do not correctly perceive the tariff structure of water. In addition, the fact that water cost represents a very small fraction of the company's total costs should not be ignored, which means that water use decisions are, in many cases, secondary decisions determined by strategic decisions on technology and production volume.

In this sense, the applied literature has showed that, in general, in sectors with less intensive use of water, the direct price elasticity of water tends to be not significant. In contrast, those with a higher share of water in their cost structure usually have a more elastic demand (see, for example, [35,36]). Some of the sectors with highest elasticities are the food sector or the paper industry (see Table 4), both activities characterized by a large water consumption. The different water intensity also determines differences between the manufacturing and services sector, obtaining, in some cases, a greater elasticity in the services sector $[36,61,66]$ and, in other cases, in the manufactures $[29,54,82]$, possibly as a result of differences in the characteristics of the case studies. In any case, the differences in elasticities reflect that firms use water for different purposes and with different intensities and that some of which have the capacity to change their water-use techniques and others do not [82].

This fact raises the issue of distinguishing water according to its use in the production process. The classification proposed by De Rooy (1974) distinguishes water used for refrigeration, incorporation into the final product, steam generation, and plant maintenance [47]. The results are not conclusive, since, in some cases, price elasticity is greater when water is incorporated into the final product [39] and, in other cases, it is lower [47]. Again, 
differences in the characteristics of the case studies may be the cause of such apparently contradictory results.

In this regard, the attention given to the spatial dimension has been very scarce in this literature. There are no previous studies obtaining and comparing elasticities for several countries or regions, although the studies focused on developing countries concluded that the elasticities they obtained are greater than those obtained in other studies for developed countries. In the developing countries, values range between -0.85 [26] and -3.0 [34], with a median value of -1.05 .

In any case, the dominant position in the literature is that the demand for water is elastic enough to allow policy makers to use the price as an instrument for water management that incentivize water efficiency. However, the use of elasticities to design a water pricing policy may have some limitations beyond the accuracy in its calculation. Thus, a pricing policy based on estimated elasticities assumes that the magnitudes of these estimations are valid for the price levels of the newly established tariff. But this assumption may not be true in reality, so the desired consumption reduction due to a price increase may not be effectively achieved [105].

The level of production is another relevant factor that influences water demand. The results obtained in the literature show, as one would expect, a positive output elasticity, indicating that those companies with a higher production level use a greater amount of water. Values range between 0.18 [82] and 2.85 [65], although this elasticity is usually less than unit (median value is 0.46 ). Moreover, results vary when considering different estimation techniques, specification of the variables, or industrial activities. In this regard, although results are not unanimous, sectors characterized by a large water consumption, such as the food industry, seem to have highest elasticities [25,35,53,62].

Finally, Table 5 shows the results obtained when analysing the relationship between water and the other inputs. For this purpose, different measures of elasticity are used in the literature: cross-price elasticity, constant output cross-price elasticity, Allen's partial substitution elasticity (ASE), or Morishima's substitution elasticity (MSE). Here, heterogeneity is the characteristic feature, with some papers finding a relationship of substitutability and others of complementarity among the same productive factors. The results are, therefore, not conclusive, although there are more papers that obtain a substitutability relationship between water and capital, labour and supplies, and a complementary relationship between water and energy.

In addition, the results obtained in the literature do coincide in pointing out the existence of an asymmetric relationship between water and the other inputs. That is, the effect of a variation in the price of water on the quantity demanded of the other inputs is very limited (the elasticity being almost zero in all cases), whereas the effect of a variation in the price of the other inputs on the quantity demanded of water is greater $[18,22,35,36,38-41,106]$. This asymmetry might be attributed to the reduced magnitude of the price of water and the low weight that this input represents in the cost share of companies. 
Table 5. Relationship between water and other inputs.

\begin{tabular}{|c|c|c|c|c|c|}
\hline Reference & Elasticity & $\begin{array}{l}\text { Water- } \\
\text { Capital }\end{array}$ & $\begin{array}{l}\text { Water- } \\
\text { Labour }\end{array}$ & $\begin{array}{l}\text { Water- } \\
\text { Energy }\end{array}$ & $\begin{array}{l}\text { Water- } \\
\text { Supplies }\end{array}$ \\
\hline \multicolumn{6}{|l|}{ Total intake water } \\
\hline De Rooy (1974) & Cross-price elasticity & & $\mathrm{S}$ & & \\
\hline Dachraoui and Harchaoui (2004) & ASE & $\mathrm{S}$ & $\mathrm{S}$ & & \\
\hline Dupont and Renzetti (2001) & Constant output cross-price elasticity & $S^{*}$ & $S$ & $S^{*}$ & $C^{*}$ \\
\hline Féres et al. (2012) & Cross-price elasticity & & & $\mathrm{C}$ & \\
\hline Féres and Reynaud (2005) & Cross-price elasticity & $\mathrm{S}^{*}$ & $\mathrm{~S}^{*}$ & S & $C^{*}$ \\
\hline Guerrero (2005) & $\begin{array}{c}\text { Constant output cross-price elasticity, ASE, } \\
\text { and MSE }\end{array}$ & & $S^{*}$ & & $S^{*}$ \\
\hline Kumar (2006) & $\begin{array}{c}\text { Constant output cross-price elasticity and } \\
\text { ASE } \\
\text { MES }\end{array}$ & $\begin{array}{c}\mathrm{S} \\
\mathrm{C}^{*}\end{array}$ & $C^{*}$ & & $\mathrm{C}$ \\
\hline Linz and Tsegai (2009) & Cross-price elasticity & $\mathrm{S}$ & $\mathrm{S}$ & $\mathrm{C}$ & \\
\hline Revollo-Fernández et al. (2020) & Cross-price elasticity & $C^{*}$ & $C^{*}$ & & $\mathrm{~S}$ \\
\hline Vásquez-Lavín et al. (2020) & Cross-price elasticity & $\mathrm{S}$ & $\mathrm{S}$ & $\mathrm{C}$ & $\mathrm{S}^{*}$ \\
\hline \multicolumn{6}{|l|}{ Publicly-supplied water } \\
\hline Angulo et al. (2014) & ASE & $\mathrm{S}$ & $S$ & & $\mathrm{~S}$ \\
\hline Babin et al. (1982) & Constant output cross-price elasticity & $\mathrm{C}$ & S & & \\
\hline Gómez-Ugalde et al. (2012) & Cross-price elasticity & & & $\mathrm{C}$ & \\
\hline Gracia-de-Rentería et al. (2019) & Cross-price elasticity & $\mathrm{C}$ & $C^{*}$ & $C^{*}$ & $\mathrm{~S}$ \\
\hline Gracia-de-Rentería et al. (2021) & Cross-price elasticity & $S$ & $S$ & & $S$ \\
\hline Grebenstein and Field (1979) & Constant output cross-price elasticity & $\mathrm{C}$ & $\mathrm{S}$ & & \\
\hline Vallés and Zárate (2013) & Cross-price elasticity & $\mathrm{C}$ & C & & $C^{*}$ \\
\hline
\end{tabular}

Notes: S, substitutive; C, complementary; ASE, Allen substitution elasticity; MSE, Morishima substitution elasticity. ${ }^{*}$ The relationship between inputs is not statistically significant at $5 \%$.

\subsection{Other Water Inputs: Self-Supplied and Recirculated Water}

Empirical studies analysing alternative water sources aimed at answering three main questions: (i) what factors determine the decision to self-supply and recirculate and the volume of water finally self-supplied and recirculated; (ii) what is the value of the direct price elasticity for the different water inputs; and (iii) what relationship, complementarity or substitutability, exists between the different water inputs.

Regarding the first question, the few studies that analysed it found that the factors that determine both the decision to self-supply and the volume of water finally self-supplied are the level of activity, the price of the water inputs, and the sector of activity [53-55]; these are similar factors to those influencing publicly supplied water. Other factors that condition the access to self-supply are the location [55,56], the end use of water, and stationarity [56]. All these drivers are similar to those that also determine the decision to recirculate water and the quantity of water recirculated [50-52], in addition to other factors: if any water treatment is needed before water being used in the production process [50,52], if the company uses self-supplied water, and the price of capital and energy [51].

Regarding the second question (see Table 4), only two papers obtained statistically significant direct price elasticities obtained for self-supplied water, with values of -0.31 [53] and -0.50 [55]. Elasticities for recirculated water range between -0.24 [52] and -1.83 [49], with a median value of -0.55 . The direct price elasticities obtained for the different water inputs in the same analysis show that self-supplied water demand is less sensitive to changes in its price than publicly supplied water [53,54]. The reason may be the higher cost of the latter, since the former is usually obtained at a very low price or even zero. On the contrary, a higher direct price elasticity is obtained for the demand for recirculated water than for the total intake water $[24,48,49]$. Moreover, water recirculation also influences the direct price elasticity of publicly supplied water, which is usually higher for companies that recirculated [51]. This may be due to the possibilities of substitution between intake and recirculated water, as confirmed by the literature responding to the third question, together with the fact that these companies usually have high water expenditures, making them more sensitive to changes in prices. 
Regarding the third question (see Table 6), only Reynaud (2003) found a relationship of complementarity between publicly and self-supplied water (although not statistically significant) [54]. The rest of the literature agrees in pointing out that the different water inputs are substitutes. The consequence of the substitutability between alternative water sources and publicly supplied water is likely to be an increase in the price elasticity of the latter.

Table 6. Relationship between the different water inputs.

\begin{tabular}{|c|c|c|c|}
\hline Reference & Elasticity & $\begin{array}{l}\text { Self-Supplied- } \\
\text { Publicly-Supplied }\end{array}$ & $\begin{array}{l}\text { Recirculated- } \\
\text { Total Intake }\end{array}$ \\
\hline Bruneau et al. (2010) & Cross-price elasticity & - & $\mathrm{S}$ \\
\hline Dupont and Renzetti (1998) & ASE & - & S \\
\hline Dupont and Renzetti (2001) & $\begin{array}{l}\text { Constant output cross-price } \\
\text { elasticity }\end{array}$ & - & $S$ \\
\hline Féres et al. (2012) & Cross-price elasticity & - & $\mathrm{S}$ \\
\hline Gracia-de-Rentería et al. (2020) & Cross-price elasticity & S & - \\
\hline Renzetti (1988) & $\begin{array}{c}\text { Constant output cross-price } \\
\text { elasticity }\end{array}$ & - & $S$ \\
\hline Renzetti (1992) & ASE & - & $\mathrm{S}$ \\
\hline Reynaud (2003) & Cross-price elasticity and ASE & $C^{*}$ & - \\
\hline
\end{tabular}

Notes: S, substitutive; C, complementary; ASE, Allen substitution elasticity. ${ }^{*}$ The relationship between water inputs is not statistically significant at $5 \%$.

\section{Conclusions}

This review of the literature about the economic determinants of industrial water demand has pursued two objectives: first, to analyse the most relevant methodological issues in this research field; second, to summarise and discuss the main results obtained by this literature. The information derived from the first objective is essentially of interest for researchers focused on the estimation of the determinants of industrial water demand, whereas the summary and discussion of previous results may also be useful for policy makers on water management.

The price of water and the output level are the determinants of industrial water demand that have been most considered in the literature. The results obtained indicate that water demand is inelastic but elastic enough to use water prices as an instrument to promote water conservation and that the volume of water demanded is strongly influenced by the production level. Elasticities are highly influenced by the sector of activity, since those sectors with a greater share of water in total costs tend to be more sensitive to changes in the price of water. The impact of other input prices on industrial water demand has been also tackled in the literature, when possible. However, conclusions about the sustainability or complementarity relationship between water and other inputs is not clear. Finally, a small body of the literature analysed the relationship between different water inputs, obtaining evidence on a substitutability relationship between them. In any case, more updated studies are required to have elasticities based on the current price levels and productive characteristics, as recently pointed out by the European Environment Agency [16], to expand the number of countries analysed and to implement more updated methodologies.

In this regard, one of the main conclusions that emerge from the review of the literature is that the results obtained are strongly conditioned by the methodological approach developed, but at the same time, the approach selected mainly depends on the data available. Therefore, to advance in this field of study, the first challenge is to have adequate data on industrial water consumption. This challenge also involves the need to obtain information about all the variables needed to model industrial water demand. 
On the one hand, the diverse water inputs used by industry (publicly supplied, selfsupply, and recirculation) should be considered separately, although until now most papers only consider publicly supplied water for being the only water source with official records or consider the total water intake without separating by source. The lack of consideration of other water sources implies that the elasticities obtained may be overestimating the effect of the variables on the total volume of water used if the companies can substitute one type of water by other. On the other hand, it is necessary to obtain information about the level of output, the price of all the production inputs (water, capital, labour, and supplies), the cost that each of them represents over the total cost, and the sector of activity. This information allows specification of a cost function in which water is included as an additional production factor, which is clearly the most suitable approach to analyse the determinants of industrial water demand for capturing the economic context from which the industrial demand for water comes.

In addition, information on the variables should be captured in microdata, which is the most suitable basis for this field of study, rather than in aggregate data often used by researchers due to the difficulties in accessing microdata and preferably referring to a long period of time and a large sample of firms. Coverage of all industrial sectors by the sample of firms is also desirable, although it is not very usual in the literature, in order to have information representative of the real production structure. In fact, the sector of activity plays a crucial role to model water demand, since it reflects sectoral differences in the use of water, the production process, and the productive technology.

To overcome the limitations in data availability highlighted by this literature review, partnership between researchers and water utilities should be promoted in order to have datasets about urban water with the required dimension and detail. Also a closer collaboration with firms is necessary to share information about the other inputs, including the water not metered by water suppliers, and on their level of output. It would also help if official statistics offices were to collect and publish data about water use as disaggregated as possible in addition to economic data on the activity of industrial enterprises. For these purposes, the Sustainable Development Goals (SDG) [107] can provide a reference framework for the promotion of public and private initiatives at different scales that, with the aim of enhancing the efficiency in the use of water and thus achieving the SDG 6, can promote research in this field and collaboration to have the information necessary for its progress.

Other methodological issues that need to receive more attention in the future are the application of tests to select the most appropriate functional form and also to select the most suitable specification of variables, especially in the case of the price of water, as well as to analyse their impact on elasticities. The incorporation of dynamics to the models and the analysis of the statistical properties of the series are also technical requirements that should be considered in the future studies to make the estimates robust. Finally, consistent with the importance of the heterogeneity of the industrial activity sectors, proposed solutions that go beyond the incorporation of dummies or estimation by sectors, such as the use of quantile regressions, should be sought.

Author Contributions: All authors have equally contributed to this review. All authors have read and agreed to the published version of the manuscript.

Funding: This research was funded by the Government of Aragón and the European Regional Development Fund through the research groups “Economía Publica” (project number S23_20R), and “Economía Agroalimentaria y de los Recursos Naturales" (project number S01_20R).

Institutional Review Board Statement: Not applicable.

Informed Consent Statement: Not applicable.

Data Availability Statement: Not applicable.

Conflicts of Interest: The authors declare no conflict of interest. 


\section{References}

1. UN Environment. Global Environment Outlook-GEO-6: Healthy Planet, Healthy People; United Nations Environment Programme (UNEP): Nairobi, Kenya, 2019.

2. World Bank. Water Resources Management; World Bank: Washington, DC, USA, 1993.

3. Organisation for Economic Co-operation and Development (OECD). Managing Water for All. An OECD Perspective on Pricing and Financing; OECD Publishing: Paris, France, 2009.

4. European Environment Agency (EEA). Towards Efficient Use of Water Resources in Europe; EEA Report 1/2012; EEA: Copenhagen, Denmark, 2012.

5. United Nations World Water Assessment Programme (WWAP). The United Nations World Water Development Report 2017: Wastewater: The Untapped Resource; UNESCO: Paris, France, 2017.

6. Renzetti, S. Commercial and industrial water demands. In The Economics of Water Demand; Renzetti, S., Ed.; Kluwer Academic: London, UK, 2002; pp. 35-49.

7. De Gispert, C. The Economic Analysis of Industrial Water Demand: A Review. Environ. Plan. C Gov. Policy 2004, 22, 15-30. [CrossRef]

8. Worthington, A. Commercial and industrial water demand estimation: Theoretical and methodological guidelines for applied economics research. Estud. Econ. Apl. 2010, 28, 237-258.

9. Arbués, F.; García Valiñas, M.A.; Martínez-Espiñeira, R. Estimation of residential water demand: A state-of-the-art review. J. Socio Econ. 2003, 32, 81-102. [CrossRef]

10. Dalhuisen, J.M.; Florax, R.J.G.M.; de Groot, H.L.F.; Nijkamp, P. Price and income elasticity of residential water demand: A meta-analysis. Land Econ. 2003, 79, 292-308. [CrossRef]

11. Worthington, A.C.; Hoffman, M. An empirical survey of residential water demand modeling. J. Econ. Surv. 2008, 22, 842-871. [CrossRef]

12. Nauges, C.; Whittington, D. Estimation of water demand in developing countries: An overview. World Bank Res. Obs. 2009, 25, 263-294. [CrossRef]

13. Sebri, M. A meta-analysis of residential water demand studies. Environ. Dev. Sustain. 2013, 16, 499-520. [CrossRef]

14. Bich-Ngoc, N.; Teller, J. A review of residential water consumption determinants. In Computational Science and Its ApplicationsICCSA 2018, Melbourne, Australia, 2-5 July 2018; Gervasi, O., Murgante, B., Misra, S., Stankova, E., Torre, C.M., Rocha, A.M.A.C., Taniar, D., Apduhan, B.O., Tarantino, E., Ryu, Y., Eds.; Springer: Cham, Germany, 2018; pp. 685-696.

15. Marzano, R.; Rougé, C.; Garrone, P.; Grilli, L.; Harou, J.; Pulido-Valazquez, M. Determinants of the price response to residential water tariffs: Meta-analysis and beyond. Environ. Model. Softw. 2018, 101, 236-248. [CrossRef]

16. Dige, G.; De Paoli, G.; Agenais, A.L.; Strosser, P.; Anzaldua, G.; Rouillard, J.; Trolzsch, J.; Hizmann, M. Pricing and Non-Pricing Measures for Managing Water Demand in Europe; Service Contract No 3415/B2015/EEA.56130; European Environment Agency: Copenhagen, Denmark, 2017.

17. Turnovsky, S. The demand for water: Some empirical evidence on consumers' commodity uncertain in supply. Water Resour. Res. 1969, 5, 350-361. [CrossRef]

18. Grebenstein, C.R.; Field, B.C. Substituting for water inputs in U.S. manufacturing. Water Resour. Res. 1979, 15, 228-232. [CrossRef]

19. Berndt, E.; Wood, D.O. Technology, prices, and the derived demand for energy. Rev. Econ. Stat. 1975, 57, 376-384. [CrossRef]

20. Griffin, J.M.; Gregory, P.R. An intercountry translog model of energy substitution responses. Am. Econ. Rev. 1976, 66, 845-857.

21. Moroney, J.R.; Toevs, A. Factor costs and factor use: An analysis of labour, capital and natural resource inputs. South. Econ. J. 1977, 44, 222-239. [CrossRef]

22. Babin, F.J.; Willis, C.E.; Allen, G. Estimation of substitution possibilities between water and other production inputs. Am. J. Agric. Econ. 1982, 64, 148-151. [CrossRef]

23. Ziegler, J.A.; Bell, S.E. Estimating demand for intake water by self-supplied firms. Water Resour. Res. 1984, 20, 4-8. [CrossRef]

24. Dupont, D.P.; Renzetti, S. Water use in the Canadian food processing industry. Can. J. Agric. Econ. 1998, 46, 83-92. [CrossRef]

25. Malla, P.B.; Gopalakrishnan, C. The economics of urban water demand: The case of industrial and commercial water use in Hawaii. Int. J. Water Resour. Dev. 1999, 15, 367-374. [CrossRef]

26. Linz, T.; Tsegai, D.W. Industrial Water Demand Analysis in the Middle Olifants Sub-Basin of South Africa; Center for Development Research (ZEF), Bonn University: Bonn, Germany, 2009.

27. Lynne, G.D. Water price responsiveness and administrative regulation: The Florida example. South. J. Agric. Econ. 1977, 9, 137-143. [CrossRef]

28. Lynne, G.D.; Luppold, W.; Kiker, C. Water price responsiveness of commercial establishments. J. Am. Water Resour. Assoc. 1978, 14, 719-729. [CrossRef]

29. Hussain, I.; Thrikawala, S.; Barker, R. Economic analysis of residential, commercial and industrial uses of water in Sri Lanka. Water Int. 2002, 27, 183-193. [CrossRef]

30. Angulo, A.M.; Atwi, M.; Barberán, R.; Mur, J. Economic analysis of the water demand in the hotels and restaurants sector: Shadow prices and elasticities. Water Resour. Res. 2014, 50, 6577-6591. [CrossRef]

31. Deyà-Tortella, B.; Garcia, C.; Nilsson, W.; Tirado, D. The effect of the water tariff structures on the water consumption in Mallorcan hotels. Water Resour. Res. 2016, 52, 6386-6403. [CrossRef] 
32. Wang, H.; Lall, S. Valuing water for Chinese industries: A marginal productivity analysis. Appl. Econ. 2002, 34, 759-765. [CrossRef]

33. Dachraoui, K.; Harchaoui, T.M. Water Use, Shadow Prices and the Canadian Business Sector Productivity Performance; Statistics Canada: Ottawa, ON, Canada, 2004.

34. Nahman, A.; De Lange, W. Valuing Water for South African Industries: A Production Function Approach; CSIR Report No. CSIR/NRE/SUSET/ER/2012/0049/A; Council for Scientific and Industrial Research: Pretoria, South Africa, 2012.

35. Gracia-de-Rentería, P.; Barberán, R.; Mur, J. Urban water demand for industrial uses in Spain. Urban Water J. 2019, 16, 114-124. [CrossRef]

36. Gracia-de-Rentería, P.; Barberán, R.; Mur, J. Urban water demand for manufacturing, construction and service industries. A microdata analysis. AQUA-Water Infrastruct. Ecosyst. Soc. 2021, 70, 274-288.

37. Revollo-Fernández, D.A.; Rodríguez-Tapia, L.; Morales-Novelo, J.A. Economic value of water in the manufacturing industry located in the Valley of Mexico Basin, Mexico. Water Resour. Econ. 2020, 30, 100138. [CrossRef]

38. Vásquez-Lavín, F.; Vargas, L.; Hernández, J.I.; Ponce, R.D. Water demand in the Chilean manufacturing industry: Analysis of the economic value of water and demand elasticities. Water Resour. Econ. 2020, 32, 100159. [CrossRef]

39. Dupont, D.P.; Renzetti, S. The role of water in manufacturing. Environ. Resour. Econ. 2001, 18, 411-432. [CrossRef]

40. Féres, J.; Reynaud, A. Assessing the impact of environmental regulation on industrial water use: Evidence from Brazil. Land Econ. 2005, 81, 396-411. [CrossRef]

41. Kumar, S. Analysing industrial water demand in India: An input distance function approach. Water Policy 2006, 8, 15-29. [CrossRef]

42. Vallés, J.; Zárate, A. Environmental taxation and industrial water use in Spain. Investig. Reg. 2013, 34, $133-164$.

43. Nauges, C.; Strand, J. Estimation of non-tap water demand in Central American cities. Resour. Energy Econ. 2007, $29,165-182$. [CrossRef]

44. Cheesman, J.; Bennett, J.; Son, T.V.H. Estimating household water demand using revealed and contingent behaviors: Evidence from Vietnam. Water Resour. Res. 2008, 44, W11428. [CrossRef]

45. Nauges, C.; Van der Berg, C. Demand for piped and non-piped water supply services: Evidence from Southwest Sri Lanka. Environ. Resour. Econ. 2009, 42, 535-549. [CrossRef]

46. Coulibaly, L.; Jakus, P.M.; Keith, J.E. Modeling water demand when households have multiple sources of water. Water Resour. Res. 2014, 50, 6002-6014. [CrossRef]

47. De Rooy, J. Price responsiveness of the industrial demand for water. Water Resour. Res. 1974, 10, 403-406. [CrossRef]

48. Renzetti, S. An econometric study of industrial water demands in British Columbia, Canada. Water Resour. Res. 1988, 24, 1569-1573. [CrossRef]

49. Renzetti, S. Estimating the structure of industrial water demands: The case of Canadian manufacturing. Land Econ. 1992, 68, 396-404. [CrossRef]

50. Bruneau, J.; Renzetti, S.; Villeneuve, M. Manufacturing firms' demand for water recirculation. Can. J. Agric. Econ. 2010, 58, 515-530. [CrossRef]

51. Féres, J.; Reynaud, A.; Thomas, A. Water reuse in Brazilian manufacturing firms. Appl. Econ. 2012, 44, 1417-1427. [CrossRef]

52. Bruneau, J.; Renzetti, S. A panel study of water recirculation in manufacturing plants. Can. Water Resour. J. 2014, 39, 384-394. [CrossRef]

53. Renzetti, S. Examining the differences in self- and publicly supplied firms' water demands. Land Econ. 1993, 69, 181-188. [CrossRef]

54. Reynaud, A. An econometric estimation of industrial water demand in France. Environ. Resour. Econ. 2003, 25, 213-232. [CrossRef]

55. Gracia-de-Rentería, P.; Barberán, R.; Mur, J. The groundwater demand for industrial uses in areas with access to drinking publicly-supplied water: A microdata analysis. Water 2020, 12, 198. [CrossRef]

56. Arbués, F.; García-Valiñas, M.A.; Villanúa, I. Making decisions on industrial water sources: The case of Zaragoza, Spain. Urban Water J. 2020, 17, 122-135. [CrossRef]

57. Tobarra-González, M.A. The Value of Water in the Manufacture Industry and its Implications for Water Demand Policies. The Case of Chile. Estud. Econ. Apl. 2018, 36, 945-960. [CrossRef]

58. Moeltner, K.; Stoddard, S. A panel data analysis of commercial customers' water price responsiveness under block rates. Water Resour. Res. 2004, 40, W01401. [CrossRef]

59. Arbués, F.; García-Valiñas, M.A.; Villanúa, I. Urban water demand for service and industrial use: The case of Zaragoza. Water Resour. Manag. 2010, 24, 4033-4048. [CrossRef]

60. Zhou, Y.; Tol, R.S.J. Water use in China's Domestic, Industrial and Agricultural Sectors: An Empirical Analysis; Working Paper FNU-67; Research Unit Sustainability and Global Change, Hamburg University and Centre for Marine and Atmospheric Science: Hamburg, Germany, 2005.

61. Bell, D.R.; Griffin, R.C. An Economic Investigation of Urban Water Demand in the U.S; Technical Report TR-331; Texas Water Resources Institute, Texas A\&M University: College Station, TX, USA, 2008.

62. Canizales, R.; Bravo, H.M. Estudio Sobre Valoración Económica y Financiera del Agua Para el Uso Industrial del Organismo de Cuenca Lema Santiago Pacífico; Technical Report; Conagua: Mexico, DF, USA, 2011.

63. Schneider, M.; Whitlatch, E.E. User-specific water demand elasticities. J. Water Resour. Plan. Manag. 1991, 117, 52-73. [CrossRef] 
64. Onjala, J. Industrial Water Demand in Kenya: Industry Behavior When Tariffs are Not Binding; Working Paper; Roskilde University: Roskilde, Denmark, 2001.

65. Mitchell, G.; McDonald, T.; Wattage, P.; Williamson, P. A standard industrial classification coded strategic planning model of industrial and commercial water demand for U.K. regions. Water Environ. J. 2000, 14, 226-232. [CrossRef]

66. Gómez-Ugalde, S.C.; Mora-Flores, J.; García-Salazar, J.A.; Valdivia-Alcalá, R. Demanda de agua para uso residencial y comercial. Terra Latinoam. 2012, 30, 337-342.

67. Stone, J.C.; Whittington, D. Industrial Water Demands. In Modeling Water Demands; Kindler, J., Russell, C.S., Eds.; Academic Press: London, UK, 1984; pp. 51-100.

68. Christensen, L.R.; Jorgeson, D.W. The measurement of U.S. real capital input, 1929-1967. Rev. Income Wealth 1969, 15, 293-320. [CrossRef]

69. Gaudet, G.O.; May, J.D.; McFetridge, D.G. Optimal capital accumulation: The neoclassical framework in a Canadian context. Rev. Econ. Stat. 1976, 58, 269-273. [CrossRef]

70. García-Valiñas, M.A. Fijación de precios para el servicio municipal de suministro de agua: Un ejercicio de análisis de bienestar. Hacienda Pública Española 2005, 172, 119-142.

71. Organisation for Economic Co-operation and Development (OECD). Pricing Water Resources and Water and Sanitation Services; OECD Publishing: Paris, France, 2010.

72. Gibbs, K. Price variable in residential water demand models. Water Resour. Res. 1978, 14, 15-18. [CrossRef]

73. Billings, R.B.; Agthe, D.E. Price elasticities for water: A case of increasing block rates. Land Econ. 1980, 56, 73-84. [CrossRef]

74. Foster, H.S.; Beattie, B. Urban residential demand for water in the United States: Reply. Land Econ. 1981, 57, 257-265. [CrossRef]

75. Opaluch, J.J. Urban residential demand for water in the United States: Further discussion. Land Econ. 1982, 58, 224-227. [CrossRef]

76. Nieswiadomy, M.L.; Molina, D.J. A note on price perception in water demand models. Land Econ. 1991, 67, 352-359. [CrossRef]

77. Barkatullah, N. OLS and Instrumental Variable Price Elasticity Estimates for Water in Mixed-Effects Model Under Multiple Tariff Structure; Working Paper No. 226; Department of Economics, University of Sydney: Sydney, Australia, 1996.

78. Martínez-Espiñeira, R. Price specification issues under block tariffs: A Spanish case study. Water Policy 2003, 5, 237-256. [CrossRef]

79. Taylor, R.G.; McKean, J.R.; Young, R.A. Alternative price specifications for estimating residential water demand with fixed fees. Land Econ. 2004, 80, 463-475. [CrossRef]

80. Ruijs, A.; Zimmermann, A.; Van der Berg, M. Demand and distributional effects of water pricing policies. Ecol. Econ. 2008, 66, 506-516. [CrossRef]

81. Baerenklau, K.A.; Schwabe, K.A.; Dinar, A. The residential water demand effect of increasing block rate water budgets. Land Econ 2014, 90, 683-699. [CrossRef]

82. Williams, M.; Suh, B. The demand for urban water by customer class. Appl. Econ. 1986, 18, 1275-1289. [CrossRef]

83. Taylor, L.D. The demand for electricity: A survey. Bell J. Econ. 1975, 6, 74-110. [CrossRef]

84. Nordin, J.A. A proposed modification of Taylor's demand analysis: Comment. Bell J. Econ. 1976, 7, 719-721. [CrossRef]

85. Shin, J.S. Perception of price when price information is costly: Evidence for residential electricity demand. Rev. Econ. Stat. 1985, 67, 591-598. [CrossRef]

86. Polzin, P.E. The specification of price in studies of consumer demand under block price scheduling: Additional empirical evidence. Land Econ. 1984, 60, 306-309. [CrossRef]

87. Borenstein, S. To What Electricity Price do Consumers Respond? Residential Demand Elasticity under Increasing-Block Pricing; Working Paper; University of California at Berkeley: Berkeley, CA, USA, 2009.

88. Ito, K. Do consumers respond to marginal or average price? Evidence from nonlinear electricity pricing. Am. Econ. Rev. 2014, 104, 537-563. [CrossRef]

89. Binet, M.E.; Carlevaro, F.; Paul, M. Estimation of residential water demand with imperfect price perception. Environ. Resour. Econ. 2014, 59, 561-581. [CrossRef]

90. Wichman, C.J. Perceived price in residential water demand: Evidence from a natural experiment. J. Econ. Behav. Organ. 2014, 107, 308-323. [CrossRef]

91. Almendarez-Hernández, M.A.; Avilés, G.; Hernández, V.; Ortega-Rubio, S.; Beltrán, L.F. Residential water demand in a Mexican biosphere reserve: Evidence of the effects of perceived price. Water 2016, 8, 428. [CrossRef]

92. Arbués, F.; Barberán, R.; Villanúa, I. Price impact on urban residential water demand: A dynamic panel data approach. Water Resour. Res. 2004, 40, W11402. [CrossRef]

93. Chambers, R. Applied Production Analysis: A Dual Approach; Cambridge University Press: Cambridge, UK, 1988.

94. Christensen, L.R.; Jorgeson, D.W.; Lau, L.J. Conjugate duality and the trascendental logarithmic production function. Econometrica 1971, 39, 255-256.

95. Revankar, N.S. A class of variable elasticity of substitution production functions. Econometrica 1971, 39, 61-71. [CrossRef]

96. McCarthy, M.D. Approximation of the CES production function: A comment. Int. Econ. Rev. 1967, 8, 190-192. [CrossRef]

97. Diewert, W.E. An application of the Shephard duality theorem: A generalized Leontief production function. J. Political Econ. 1971, 79, 481-507. [CrossRef]

98. Cardoso, M.L. Modeling Portuguese Water Demand with Quantile Regression. Ph.D. Thesis, University Institute of Lisbon, Lisbon, Portugal, 2013. 
99. Siddiquee, M.S.H.; Ahamed, R. Exploring Water Consumption in Dhaka City Using Instrumental Variables Regression Approaches. Environ. Process. 2020, 7, 1255-1275. [CrossRef]

100. Höglund, L. Household demand for water in Sweden with implications of a potential tax on water use. Water Resour. Res. 1999, 35, 3853-3863. [CrossRef]

101. Nauges, C.; Thomas, A. Long-run study of residential water consumption with an application to a sample of French communities. Environ. Resour. Econ. 2003, 26, 25-43. [CrossRef]

102. Martínez-Espiñeira, R. An estimation of residential water demand using co-integration and error correction techniques. J. Appl. Econ. 2007, 10, 161-184. [CrossRef]

103. Zaied, Y.B.; Binet, M.E. Modeling seasonality in residential water demand: The case of Tunisia. Appl. Econ. 2015, 47, 1983-1996. [CrossRef]

104. Zaied, Y.B.; Cheikh, N.B. Modeling regional water consumption in Tunisia using panel cointegration second generation tests. J. Quant. Econ. 2015, 13, 237-251. [CrossRef]

105. Brookshire, D.S.; Burness, H.S.; Chermak, J.M.; Krause, K. Western urban water demand. Nat. Resour. J. $2002,42,873-898$.

106. Guerrero, H. Industrial Water Demand in Mexico: Econometric Analysis and Implications for Water Management Policy. Ph.D. Thesis, Université de Toulouse 1, Toulouse, France, 2005.

107. General Assembly. Transforming Our World: The 2030 Agenda for Sustainable Development; Agenda items 15 and 116; United Nations, A/RES/70/1: New York, NY, USA, 2015. 